\title{
Multi-Objective Assessment of Heat Pump-Assisted Ethyl Acetate Production
}

\author{
Branislav Šulgan, Juraj Labovský, Miroslav Variny and Zuzana Labovská *
}

Institute of Chemical and Environmental Engineering, Faculty of Chemical and Food Technology, Slovak University of Technology in Bratislava, Radlinského 9, 81237 Bratislava, Slovakia; branislav.sulgan@stuba.sk (B.S..); juraj.labovsky@stuba.sk (J.L.); miroslav.variny@stuba.sk (M.V.)

* Correspondence: zuzana.labovska@stuba.sk; Tel.: +421-918-674-251

Citation: Šulgan, B.; Labovský, J.; Variny, M.; Labovská, Z. Multi-

Objective Assessment of Heat

Pump-Assisted Ethyl Acetate

Production. Processes 2021, 9, 1380.

https://doi.org/10.3390/pr9081380

Academic Editors: Arturo JiménezGutiérrez and Gabriel SegoviaHernandez

Received: 30 June 2021

Accepted: 5 August 2021

Published: 6 August 2021

Publisher's Note: MDPI stays neutral with regard to jurisdictional claims in published maps and institutional affiliations.

Copyright: (C) 2021 by the authors. Licensee MDPI, Basel, Switzerland. This article is an open access article distributed under the terms and conditions of the Creative Commons Attribution (CC BY) license (https:// creativecommons.org/licenses/by/ $4.0 /)$.

\begin{abstract}
Multi-objective (energy-economic-safety) assessment of ethyl acetate production involving a heat pump is presented in this paper. The heat pump is designed to intensify ethyl acetate separation and to reduce the total operating cost. Two ethyl acetate production pathways are upgraded using a heat pump, conventional process and reactive distillation column with a separation unit. Detailed process models including the heat pump environment have been compiled and optimized in the Aspen Plus software. Both benefits and drawbacks of including the heat pump in the processes are evaluated using three different points of view: process energy, economics, and safety. As a result, using a heat pump is highly recommended in both conventional process and reactive distillation column with a separation unit. As a higher level of process integration is achieved using a heat pump, economic aspects are improved; however, safety aspects deteriorate. The final decision on the suitability of using a heat pump depends on whether it is proposed for an existing plant, or a completely new plant is designed. In a new plant, the concept of a thermally coupled process (reactive distillation column with a stripper column) has been proven to be the most promising.
\end{abstract}

Keywords: reactive distillation; ethyl acetate; heat pump; process integration and intensification; energy-economic-safety aspects

\section{Introduction}

A substantial part of global chemical production is made of organic solvents, the production of esters being one of the key segments. Wide industrial application, reasonable price, low toxicity and suitable properties of ethyl acetate as a solvent are known $[1,2]$. Therefore, the demand for ethyl acetate has steadily increased in recent years and its global consumption is also expected to increase in the future. Consequently, it is essential to boost ethyl acetate production. The approach to intensification of ethyl acetate production can be based on streamlining and improving existing processes or on designing an alternative, much more efficient, process compared to the conventionally used ones.

Three main chemical paths of ethyl acetate industrial production based on ethylene acetylation, ethanol dehydrogenation and Fisher esterification are commonly used. When considering economic and safety aspects, the first two paths have been appointed as inappropriate [2]. On the other hand, esterification is much preferred considering the availability of raw materials from renewable sources, applicability of different catalysts and overall process economics. Moreover, the high potential for process intensification and integration is assumed in case of direct Fisher esterification [3].

The most widespread commercial ethyl acetate production path using Fisher esterification includes a continuous stirred tank reactor (CSTR) and a separation system. The task of the separation system is to ensure sharp split of the products. Commonly, three distillation columns including an azeotropic distillation column and a decanter are used [4,5]. Despite several options for columns and recycles integration, this process is energy-intensive [6]. Moreover, a large amount of recycling is used due to the distillation boundary limitation 
and the equipment also has to be relatively large [5]. At present, the reduction in energy consumption and improvement of process economics of ethyl acetate production is linked with overcoming the limitations associated with the separation of equilibrium esterification reaction products; in particular, separation of azeotropic mixtures formed during the production process, distillation boundaries and by-product removal. All the above-mentioned tasks can be challenged by implementing a well know process-reactive distillation (RD). The concept of RD combining chemical reaction and separation in one unit has shown great potential in the production of esters generally [3,4,7]. Consequently, industrial-scale plants combining a reactive distillation column with a separation unit producing ethyl acetate can be found all over the world [4,7].

\subsection{Reactive Distillation Process Intensification and Integration}

In general, further intensification and integration of the RD process can be achieved by applying physical, chemical and mechanical methods $[3,8]$. In case of ethyl acetate production, all three methods have been tested.

The separation can be enhanced by physical methods: the addition of selective solvent (azeotropic reactive distillation [3], reactive extractive distillation [9]) or by changing operation conditions (pressure-swing RD [4]). Chemical methods are based on employing an auxiliary chemical reaction to remove the by-product of the main reaction while obtaining another valuable product. The main process chemical reaction and separation are improved simultaneously (reactive distillation with an auxiliary chemical reaction $[5,10]$ ). Mechanical ways of RD intensification are focused on the use of special internal equipment of columns to ease the separation (reactive distillation with a dividing wall (RDWC) [11] or reactive distillation with pervaporation (RDPV) [3,7]), which intensifies the chemical reaction (special catalyst beds in case of a heterogeneous catalyst) [3,12]. Special attention is given to integrated columns with strippers (RDS) [5], recompression of overheated vapor, etc. $[8,13]$. A heat pump can be applied to upgraded both reactive distillation and conventional distillation process at certain conditions [14].

\subsection{Heat Pumps Integration}

An obvious way to achieve energy integration is to couple the condenser and reboiler as they represent the major source and sink of energy, respectively [14]. The condenser and the reboiler can be connected by means of a heat pump (HP) to be energy efficient. Several types of heat pumps using different mechanism are known considering their mechanism which is commonly based on vapor compression, mechanical vapor recompression, thermal vapor recompression, absorption and compression resorption [15]. The applicability of individual HP type follows careful investigation of heat integration possibilities based on the well-known Pinch analysis [16].

A specific fluid is used as a heat transfer medium running between the heat source and sink in case of vapor compression HP (in Figure 1a) requiring a compressor to provide external work input. The HP loop is closed by a throttle valve. Since all these elements are external to the distillation process, the distillation column does not require major modifications except for the adjustments in the heat exchangers due to the change in utilities [14].

Instead of a specific fluid, column overhead vapor can be used as the heat carrier medium fed directly to a compressor. The resulting configuration is referred to as the mechanical vapor recompression heat pump (MVRHP) (Figure 1b), the overhead vapor is compressed to a higher pressure to increase its temperature and energy content and can be used as a heating medium in the column reboiler [17,18]; alternatively, the bottom liquid is flashed in a valve and can be used to condense the overhead vapor. The MVRHP performs well at small temperature difference between the overhead and bottom of the distillation column (less than $20^{\circ} \mathrm{C}$ ) $[14,19]$. The MVRHP serves also as the condenser, i.e., one heat exchanger is missing compared to the vapor compression HP. Moreover, the MVRHP shows higher efficiency compared to the vapor compression HP. However, 
the MVRHP does not directly tackle the main drawback of the vapor compression HP: the economic penalty of using an expensive compressor for large temperature lifts $[14,15]$.

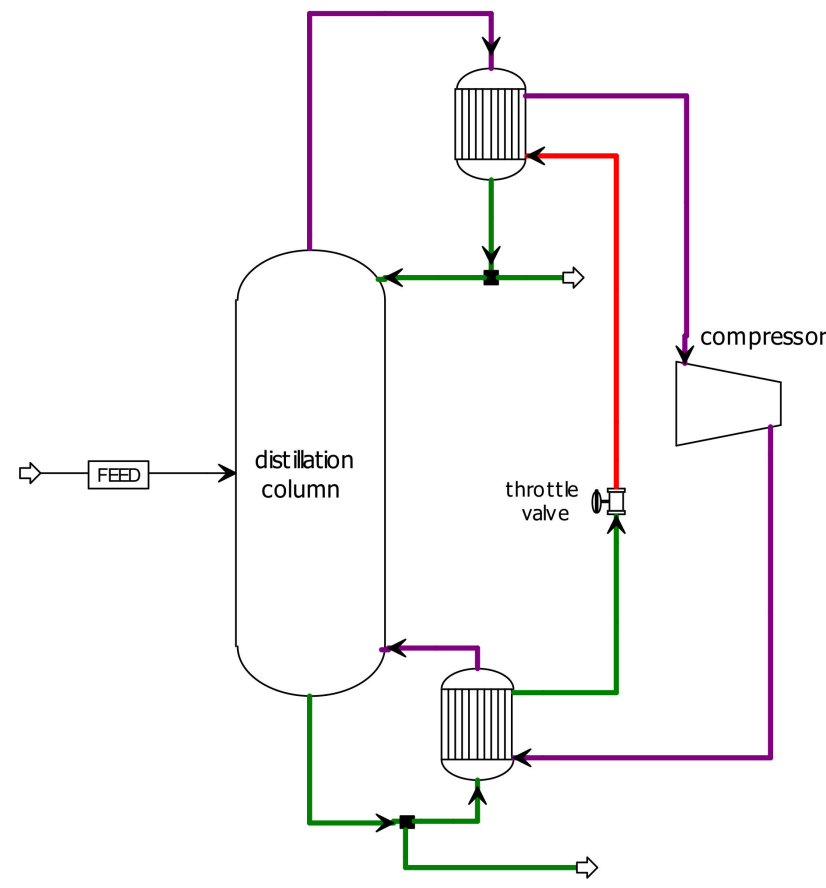

(a)

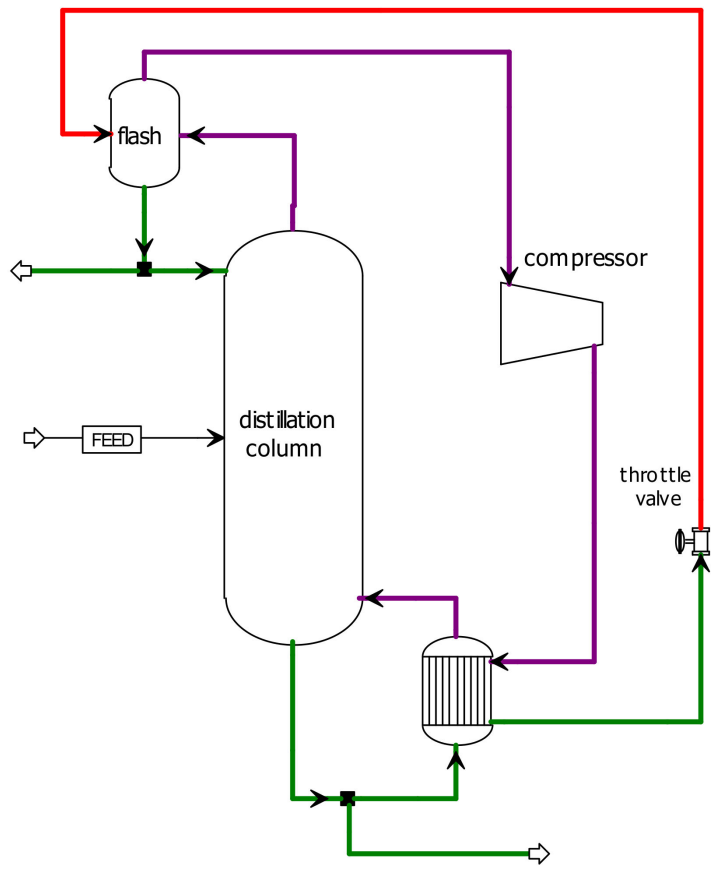

(b)

Figure 1. Heat pumps schemes: (a) Vapor compression heat pump; (b) Mechanical vapor recompression heat pump. Stream condition: green-liquid at boiling temperature; red-vapor-liquid mixture; purple—saturated/overheated vapor.

\subsection{Current Trends of Heat Pump Application in Separation Processes}

The concept of heat pump integration has been very intensely researched for various systems, comprising both binary and ternary mixtures. Several heat pump applications in separation processes discussed in recent literature are summarized in Table 1. Mostly, Aspen Plus or Aspen Hysys are employed as robust and reliable computational tools nowadays. Matlab can be employed for optimization calculations, as presented by Christopher [20] or Feng [21]. Most studies focus on economic or coupled economic-environmental optimization, in line with the current approach to industrial processes optimization described by Dai [22] and Sharon [23], selecting total annual cost (TAC), annual operation cost (AOC) and similar factors as economic indicators [24-27], while $\mathrm{CO}_{2}$ emissions serve as environmental performance indicator [28-30]. Other issues such as material efficiency described by Parmar [31], thermal efficiency used by Feng [21], or process control designed by Shi [30] are not often included in the optimization scheme. As documented in Table 1, risk assessment was mentioned only by Parmar [31] and even there it is constrained on heuristic evaluation only. The inclusion of quantitative risk assessment into multi-objective optimization of industrial processes is a very recent topic (Ifaei [32]), and the effect of heat pump integration into a process is not well explored. 
Table 1. Current state of research on heat pumps application.

\begin{tabular}{|c|c|c|c|c|c|}
\hline Study & System & Modeling & Objectives & $\begin{array}{l}\text { Results, Comparison to } \\
\text { Conventional Process }\end{array}$ & Reference \\
\hline Klauzner et al. (2020) & $\begin{array}{c}\text { Extractive distillation of } \\
\text { isobutanol- } \\
\text { isobutyl acetate }\end{array}$ & Aspen Plus V9 & $\begin{array}{l}\text { TAC, cost of energy } \\
\text { carriers }\end{array}$ & $\begin{array}{c}\text { Energy carrier costs } \\
\text { reduced by } 56 \%, \\
\text { TAC reduced by } 30.7 \%\end{array}$ & [24] \\
\hline $\begin{array}{l}\text { Shi et al. } \\
(2020)\end{array}$ & $\begin{array}{c}\text { Extractive distillation of } \\
\text { Ethanol-tert } \\
\text { butanol-water }\end{array}$ & Aspen Plus V10 & $\begin{array}{l}\text { Payback period, TAC, } \\
\mathrm{CO}_{2} \text { emissions, total } \\
\text { emissions }\end{array}$ & $\begin{array}{l}\mathrm{CO}_{2} \text { emissions decreased } \\
\text { by } 47 \% \text {, higher TAC }\end{array}$ & [25] \\
\hline $\begin{array}{l}\text { Zhang et al. } \\
\qquad(2020)\end{array}$ & $\begin{array}{l}\text { Isopropanol-butanol- } \\
\text { ethanol separation from } \\
\text { fermentation broth }\end{array}$ & Aspen Plus V10 & $\mathrm{TAC}, \mathrm{CO}_{2}$ emissions & $\begin{array}{c}\text { Annual operation cost } \\
\text { decrease by } 44 \%, 30.5 \% \\
\text { reduction in } \mathrm{CO}_{2} \text { emissions }\end{array}$ & [26] \\
\hline $\begin{array}{l}\text { Cong et al. } \\
\text { (2018) }\end{array}$ & $\begin{array}{l}\text { Model binary and } \\
\text { ternary mixtures }\end{array}$ & Aspen Plus V7.2 & $\begin{array}{c}\text { TAC, annual } \\
\text { operating cost (AOC) }\end{array}$ & $\begin{array}{l}\text { TAC and AOC savings with } \\
\text { different configurations }\end{array}$ & [27] \\
\hline $\begin{array}{l}\text { Christopher et al. } \\
\text { (2017) }\end{array}$ & Propane-propylene & $\begin{array}{l}\text { Aspen Hysys + } \\
\text { Matlab }\end{array}$ & $\begin{array}{c}\text { Energy consumption, } \\
\text { annualized } \\
\text { separation costs } \\
\text { (ASC) }\end{array}$ & $\begin{array}{c}\text { Best configuration achieved } \\
\text { energy consumption } \\
\text { savings of } 45 \% \text { and ASC } \\
\text { saving of } 20 \%\end{array}$ & {$[20]$} \\
\hline $\begin{array}{l}\text { Parmar et al. } \\
\qquad(2020)\end{array}$ & $\begin{array}{l}\text { Propane-propylene } \\
\text { splitting in an } \\
\text { Ethylene plant }\end{array}$ & Aspen Plus & $\begin{array}{l}\text { Energy consumption, } \\
\text { propylene } \\
\text { recovery, process } \\
\text { safety }\end{array}$ & $\begin{array}{c}\text { Energy consumption } \\
\text { reduction by } 68 \%, \\
\text { propylene recovery increase } \\
\text { by } 3 \% \text {, process safety } \\
\text { evaluated from experience } \\
\text { AOC savings of up to } 60 \%\end{array}$ & [31] \\
\hline $\begin{array}{l}\text { Long et al. } \\
\text { (2019) }\end{array}$ & $\begin{array}{l}\text { Separation of R410A } \\
\text { and R22 }\end{array}$ & Aspen Hysys V10 & $\begin{array}{l}\mathrm{AOC}, \mathrm{CO}_{2} \\
\text { emissions }\end{array}$ & $\begin{array}{c}\text { and } \mathrm{CO}_{2} \text { emissions saving } \\
\text { of up to } 58 \% \text { in the best } \\
\text { configuration }\end{array}$ & [28] \\
\hline $\begin{array}{l}\text { Feng et al. } \\
\qquad(2020)\end{array}$ & $\begin{array}{c}\text { Extractive distillation of } \\
\text { n-hexane and } \\
\text { ethyl acetate }\end{array}$ & $\begin{array}{l}\text { Aspen Plus V8.8 + } \\
\text { Matlab 2019a }\end{array}$ & $\begin{array}{c}\text { TAC, operating costs, } \\
\text { thermal } \\
\text { efficiency }\end{array}$ & $\begin{array}{l}\text { Operating costs reduction } \\
\text { by over } 90 \% \text {, } \\
\text { TAC reduction by } 7 \% \text {, } \\
\text { thermal efficiency increased } \\
\text { by over } 9 \%\end{array}$ & [21] \\
\hline $\begin{array}{l}\text { Duan and Li } \\
\qquad(2021)\end{array}$ & $\begin{array}{l}\text { Extractive distillation of } \\
\text { ethanol and ethyl acetate }\end{array}$ & Aspen Plus V11 & TAC, $\mathrm{CO}_{2}$ emissions & $\begin{array}{l}55 \% \text { reduction on } \mathrm{TAC} \text { and } \\
66 \% \text { reduction in } \mathrm{CO}_{2} \\
\text { emissions possible with } \\
\text { best configuration }\end{array}$ & [29] \\
\hline $\begin{array}{l}\text { Shi et al. } \\
(2020)\end{array}$ & $\begin{array}{c}\text { Extractive distillation of } \\
\text { ethanol and ethyl } \\
\text { acetate }\end{array}$ & $\begin{array}{l}\text { Genetic } \\
\text { Algorithm }\end{array}$ & $\begin{array}{c}\text { TAC, } \mathrm{CO}_{2} \text { emissions, } \\
\text { dynamic control } \\
\text { simulation }\end{array}$ & $\begin{array}{c}\text { TAC can be reduced by } \\
\text { over } 7 \% \text { and } \mathrm{CO}_{2} \text { emissions } \\
\text { by over } 9 \%\end{array}$ & [30] \\
\hline
\end{tabular}

The main goal of this paper is to assess the possibility of including a heat pump (MVRHP) in selected ethyl acetate production processes as well as to assess the benefits of such integration. Multi-objective (energy-economics-safety) assessment of primary processes was performed in our previous work [5] and integration of a heat pump is expected to lead to process intensification, significant energy savings and utility cost reduction. Both benefits and drawbacks of including a heat pump in the process have been evaluated using three different points of view: process energy, economics, and safety. Consequently, the obtained results were compared with assessment results of primary designed processes presented in our previous work [5]. Novelty of the proposed work can be summed up as follows:

> Improving designed ethyl acetate production processes;

$>$ Process integration and intensification using a heat pump;

$>$ Process integration: conventional process and reactive distillation;

$>$ Assessment of three different points of view—energy, economic, and safety aspects.

\subsection{Methodology}

In our previous work [5], a total of four ethyl acetate production pathways were designed and assessed considering energy, economic and safety indicators. The pathways ranked according to the increasing level of integration were as follows: conventional process, reactive distillation column with a separation unit, reactive distillation column with a stripper column (RDS), and reactive distillation column with an auxiliary chemical 
reaction (RDAR). An overview of the pathways' benefits and drawbacks is presented in Table 2.

Table 2. Summary of ethyl acetate production pathways from our previous work [5]; number of main equipment, process integration, benefits, drawbacks.

\begin{tabular}{|c|c|c|c|c|}
\hline & Conventional Process & $\begin{array}{l}\text { RD Column with a } \\
\text { Separation Unit }\end{array}$ & RDS & RDAR \\
\hline $\begin{array}{c}\text { number of main } \\
\text { equipment }\end{array}$ & 5 & 4 & 2 & 1 \\
\hline $\begin{array}{c}\text { number of heat } \\
\text { exchangers }\end{array}$ & 7 & 5 & 2 & 2 \\
\hline process integration & base process & reactive distillation & $\begin{array}{l}\text { reactive distillation } \\
\text { stripper column }\end{array}$ & $\begin{array}{l}\text { auxiliary reaction } \\
\text { fully integrated process }\end{array}$ \\
\hline heat integration & yes & yes & thermal coupling & $\begin{array}{c}\text { chemical reaction } \\
\text { synergy }\end{array}$ \\
\hline benefits & $\begin{array}{ll}- & \text { well know } \\
\text { - } & \text { commonly used }\end{array}$ & $\begin{array}{ll}- & \text { well know } \\
\text { - } & \text { reactive } \\
& \text { distillation } \\
\text { - } & \text { commonly used } \\
\text { - } & \text { capital savings } \\
\text { - } & \text { energy savings }\end{array}$ & $\begin{array}{ll}- & \text { know principle } \\
- & \text { the highest level } \\
\text { of integration and } \\
\text { intensification } \\
\text { - } \quad \text { capital savings } \\
\text { - } & \text { energy savings }\end{array}$ & $\begin{array}{ll}\text { - } & \text { the most } \\
\text { promising } \\
\text { - } & \text { fully integrated } \\
\text { and intensified } \\
\text { process } \\
\text { - } \quad \text { capital savings } \\
\text { - } \quad \text { energy savings } \\
\text { - } & \begin{array}{l}\text { another valuable } \\
\text { product }\end{array}\end{array}$ \\
\hline drawbacks & $\begin{array}{ll}\text { - } & \text { large plant } \\
\text { - } & \text { difficult } \\
\text { - } & \text { separation } \\
\text { - } & \text { decanter } \\
& \text { large stream } \\
& \text { recycles } \\
- & \text { energy intensive } \\
\text { - } & \text { capital cost }\end{array}$ & $\begin{array}{ll}\text { - } & \text { decanter } \\
\text { - } & \text { large stream } \\
& \text { recycles } \\
\text { - } & \text { energy intensive } \\
& \text { separation } \\
\text { - } & \text { capital cost }\end{array}$ & $\begin{array}{ll}\text { - } & \text { complex } \\
\text { - } & \text { regulation } \\
\text { process linking } \\
\text { RD column and } \\
\text { stripper } \\
\text { - } \quad \text { large stream } \\
\text { recycle }\end{array}$ & $\begin{array}{ll}\text { - } & \text { hazardous } \\
\text { reactant } \\
\text { - } \quad \begin{array}{l}\text { complex } \\
\text { regulation }\end{array} \\
\text { - } \quad \text { the need for } \\
\text { further research } \\
\text { - } \quad \text { multiple steady } \\
\text { states }\end{array}$ \\
\hline
\end{tabular}

${ }^{a}$ reactor, decanter, distillation column and RD column including column environment.

In the first step, a detailed analysis was performed to identify possible connections of the heat pump. Application of the MVRHP was preferred considering direct use of the energy potential of existing streams. Moreover, no specific fluid is needed in contrary to the vapor compression heat pump. As described in Section 1.2, the MVRHP can be used effectively when temperature difference between bottom and top of the column is less than $20^{\circ} \mathrm{C}$. Considering this condition, all four ethyl acetate production pathways (in detail presented in [5] and summarized in Table 2) were analyzed and a column appropriate for heat pump integration was selected. The column for pure ethyl acetate separation has proved to be the most promising with the temperature difference between top and bottom of the column of approximately $7{ }^{\circ} \mathrm{C}$ [5]. This column was used both in the conventional process (Figure 2) as well as in the reactive distillation process with a separation unit (Figure 3). Another reason for choosing this column is that the most energy-intensive equipment in both processes (production via conventional process set-up-Figure 2, production via reactive distillation column with a separation unit-Figure 3). Despite the possibility of using HP in RDS (Appendix A, Figure A1), this variant was omitted as RDS itself uses the principle of thermal coupling. Finally, the RDAR process was also excluded from this study because there is no potential for implementing a HP. Consequently, two ethyl acetate production paths including an MVRHP have been designed: conventional process (Figure 2) and RD column with a separation unit (Figure 3). The MVRHP was designed in a column for the separation of pure ethyl acetate (column C2 in Figure 2 or Figure 3, respectively). 


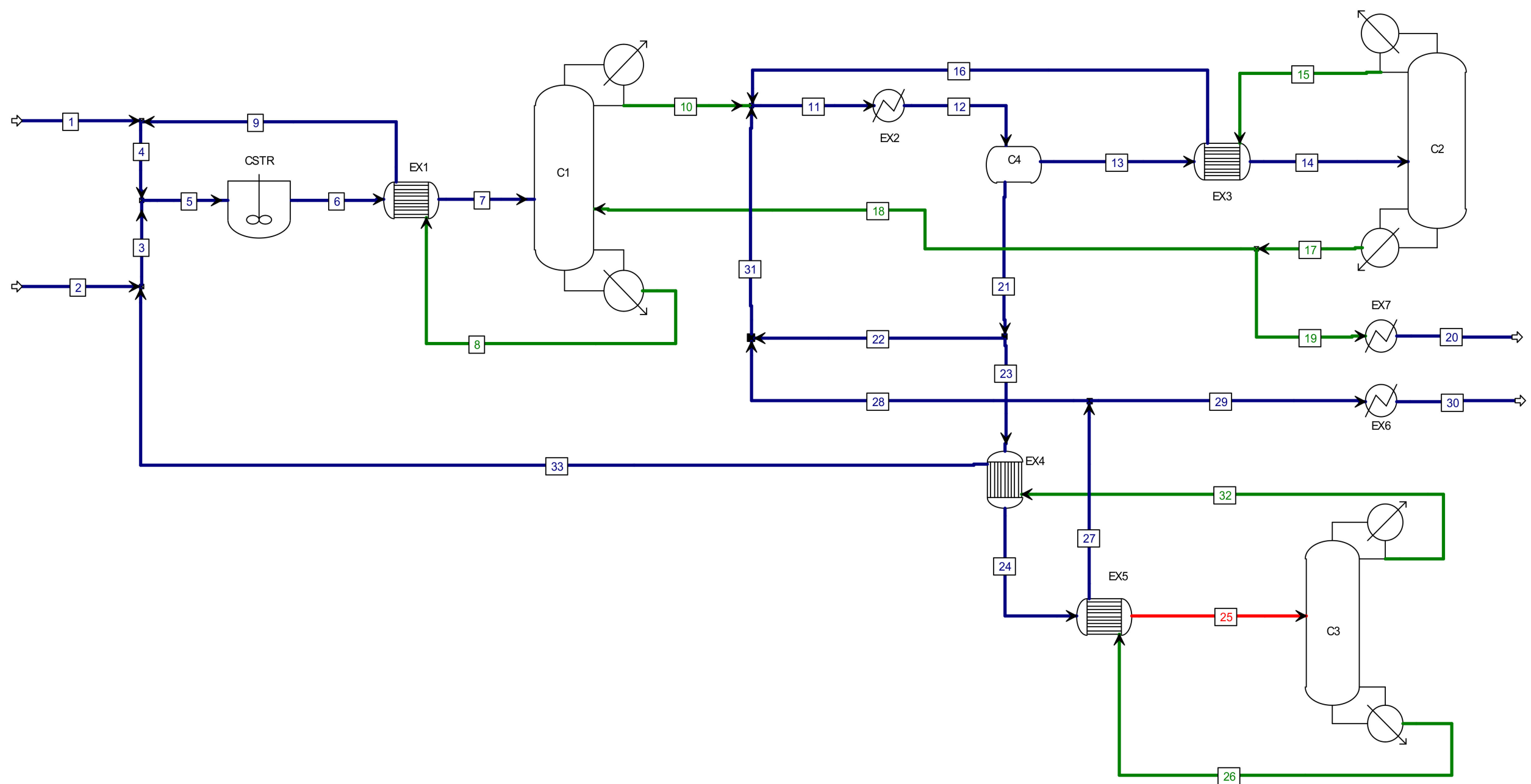

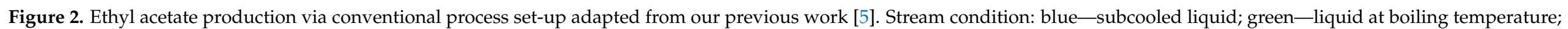
red-vapor-liquid mixture. C1—azeotropic distillation column; C2, C3—distillation columns; C4—decanter; CSTR—continuous stirred tank reactor; EX1-7-heat exchangers. 


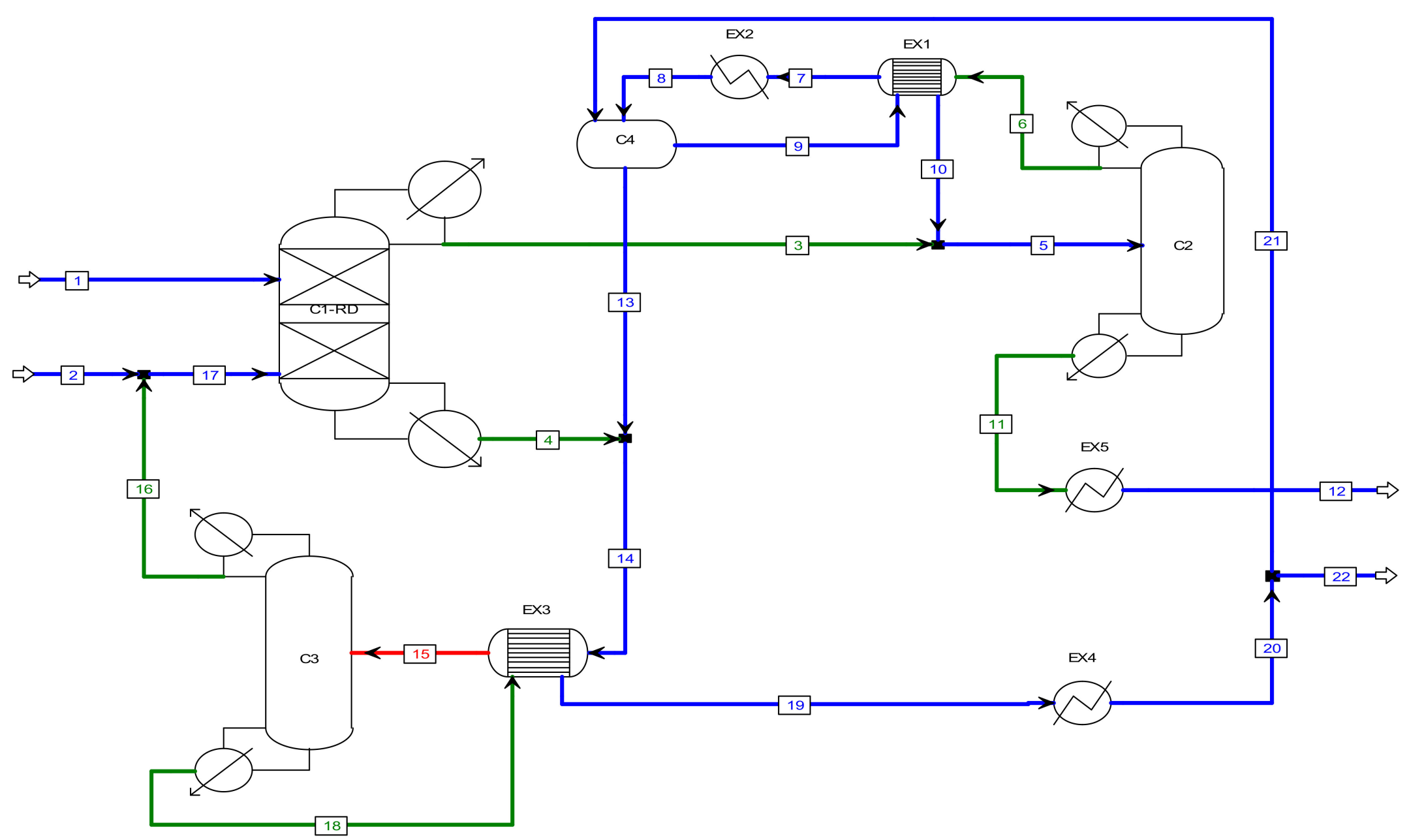

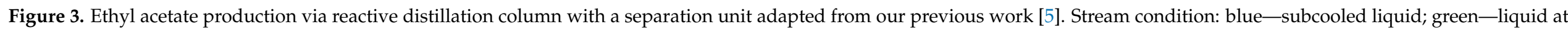
boiling temperature; red—vapor-liquid mixture. C1-RD—reactive distillation column; $\mathrm{C} 2$, C3—distillation columns; C4—decanter; EX1-5—heat exchangers. 


\subsubsection{Sustainability Indicators}

The effect of including a heat pump was monitored via several indicators including energy, economics, and safety aspects using the same approach as that described in our previous work in more details [5].

Process energy intensity is quantified by specific energy consumption (SEC) [4-6]. Efficiency of the HP is described by a coefficient of performance (COP) [26] defined by Equation (1):

$$
\mathrm{COP}=\frac{Q}{W}=\frac{T_{\mathcal{c}}}{T_{w}-T_{\mathcal{c}}}
$$

Representing the ratio of the heat required by the corresponding distillation column $(Q)$ to the electric work required by compressor $(W) . T_{C}$ and $T_{W}$ are temperatures of column condenser and reboiler, respectively $[14,26]$. Consequently, at COP of above 10, an HP is highly recommended; COP below 5 indicates no benefits of using an HP. Further, HP efficiency is evaluated via the energy saving rate of the column with HP compared to the original column. This is defined as primary energy savings (PES) [14], Equation (2).

$$
\mathrm{PES}=\left(1-\frac{\frac{W}{\eta_{E}}}{\frac{Q}{\eta_{Q}}}\right) 100 \%
$$

The PES value considers reference efficiency of both electricity $\left(\eta_{E}\right)$ and heat production $\left(\eta_{Q}\right)$. The reference efficiency is depended on a fuel source (coal, wood, natural gas, etc.) which is used to produce electricity or heat, respectively. The exact value is determined by a government directive [33].

Economic aspects were evaluated by total production cost (TPC) including total annual cost (TAC); total capital cost (TCC) and pay-back period [26,34]. The profitability of HP use was monitored by pay-back period compared to the results obtained in [5].

Safety evaluation was based on the Chemical Process Quantitative Risk Analysis, performing individual risk estimation for all case studies. The effect of the heat pump inclusion on the individual risk was monitored; original processes adopted from our previous work [5] were compared to the processes designed in this work (including HP). Individual risk was assessed as a function of distance (individual risk profiles) as described in $[5,35]$ in more details.

\section{Process Modeling}

\subsection{Chemical System Description}

Typically, the esterification process includes four compounds: alcohol, acid, ester, and water. In this work, ethanol (EtOH), acetic acid (AA), ethyl acetate (EtAc), and water $\left(\mathrm{H}_{2} \mathrm{O}\right)$ were employed. Phase equilibria of this quaternary system have been studied extensively $[6,9,36,37]$ and its non-ideality is well known. Four azeotropes are reported in literature [36,38] and databases [39] in total: one homogeneous ternary azeotrope (EtAc- EtOH- $\left.\mathrm{H}_{2} \mathrm{O}\right)$, one heterogeneous binary azeotrope $\left(\mathrm{EtAc}-\mathrm{H}_{2} \mathrm{O}\right)$ and two homogeneous binary azeotropes $\left(\mathrm{EtOH}-\mathrm{H}_{2} \mathrm{O}, \mathrm{EtOH}-\mathrm{EtAc}\right)$. In case of acetic acid, there is no azeotrope with any of the present compounds; however, it is known for its strong association in the vapor phase and for dimer formation [40]. Thus, a reliable thermodynamic model able to describe two liquid phases, azeotropic mixtures composition and boiling points, and dimerization in the vapor phase is required. Correct prediction of vaporliquid-liquid phase equilibria (VLLE) for such non-ideal system can be obtained using the NRTL-HOC thermodynamic model [39,40], which has been proven relevant in $[3,9,11,37]$ providing good agreement of simulation results and experimental data. Furthermore, reliable parameters of the NRTL-HOC model are included in widely used databases (Aspen Plus [39], DECHEMA, NIST).

Modeling of the esterification chemical reaction is based on our previous work [5], where details about reaction catalysis type, achievable conversion, reaction rate and indus- 
trial application were discussed. Homogeneous catalysis using sulfuric acid was assumed, Equation (3) with the reaction rate $\left(r\left[\mathrm{kmol} \mathrm{m}^{-3} \mathrm{~s}^{-1}\right]\right)$ expressed by Equation $(4)[5,10,12]$. As the reaction occurs in the liquid phase; liquid phase molar concentrations $\left(C\left[\mathrm{kmol} \mathrm{m}^{-3}\right]\right)$ were used neglecting the low sulfuric acid catalyst concentration [4,9] in the phase equilibria calculation.

$$
r=2.8 \times 10^{4} \exp \left(-\frac{41,868}{R T}\right) C_{A A} C_{E t O H}-7.1 \times 10^{3} \exp \left(-\frac{41,868}{R T}\right) C_{H_{2} O} C_{E t A c}
$$

\subsection{Equipment Model}

Aspen Plus simulation environment (Aspen Plus V12, Aspen Technology Inc., Bedford, MA, USA) was used for process simulation. Four main types of equipment model were employed: chemical reactor, heat exchanger, distillation/reactive distillation column and compressor.

Continuous stirred tank reactor (CSTR) with ideal mixing along with rate-controlled chemical reaction based on known kinetics was assumed as the chemical reactor model. The reactor was designed as an adiabatic one. The desired conversion was achieved by optimizing the reactor's residence time parameter. The occurrence of the esterification Reaction (3) in liquid phase and the chemical reaction rate Expression (4) were specified as inputs.

Build-in Aspen Plus models Heater and HeatX were used for heat exchangers simulation. A shortcut set-up was applied to reach the desired stream temperature. Detailed design of the heat exchanger was assumed in case of process heat exchangers using heat integration. In all heat exchangers, minimum temperature driving force was set to $10{ }^{\circ} \mathrm{C}$.

Distillation and reactive distillation processes were simulated using the rigorous RadFrac model. This model allows both equilibrium (EQ) stage and non-equilibrium (NEQ) stage approach. In this work, the NEQ stage model was used for each column. As this model is more complex, much more reliable parameters compared to the EQ stage model [5] are required and convergence problems often occur. This problem can be overcome by building the EQ stage model of each column first to use its results as a very good initial guess of stage temperature, liquid phase composition and vapor phase composition for the NEQ stage model $[37,41]$. Initial column parameters such as the number of theoretical stages $(N)$, reactive zone $\left(N_{R}\right)$, feed stage position $(f)$, reflux ratio $(R)$, column type and internals were adopted from literature [4,5].

According to the simulation-experimental papers [11,37], packed columns were selected using Rashig Ralu-Ring packing type. Mass and heat transfer were calculated using selected packing appropriated correlation methods [39]. Column hydraulics was simulated by Aspen Plus built-in hydraulic function assuming correlation for the Rashig Ralu-Ring packing type. Reasonable column hydraulics, pressure drop and approach to flooding were designed by setting the internal column parameters (internal column diameter $(d)$, packing height $(H)$, packing dimensions). In case of reactive distillation columns, esterification chemical reaction (3) was allowed in the reactive zone $\left(N_{R}\right)$; its reaction rate is expressed by Equation (4). The reactive zone was determined by acetic acid as a homogeneous catalyst (sulfuric acid) was fed to the column together with acetic acid [10,41].

A compressor was modeled applying Aspen Plus build-in model using the isentropic GPSA method [42]. The compression process non-ideality was described via efficiencies; recommended estimates were obtained from the literature [43]. Isentropic efficiency and mechanical efficiency were set to be 0.8 and 0.9 , respectively. The compressor discharge pressure was set as outlet specification, outlet pressure was adjusted to achieve a suitable 
overhead vapors condensation temperature and the required heating duty of the column reboiler. The total medium flow in the heat pump subsystem was also affected by the compressor discharge pressure and the required network $(W)$ was monitored as an energy consumption indicator.

\subsection{Simulation Goals and Design Specifications}

The simulation strategy is aimed at improving the known ethyl acetate production pathways using a heat pump. The base model concept of conventional production path and reactive distillation column with a separation unit (system) were adopted from our previous work [5]. Separation column for pure ethyl acetate was supplemented with a heat pump to reduce energy consumption of the most energy-intensive step, separation of pure ethyl acetate. Moreover, further process and heat integration were achieved. The influence of using a heat pump on energy-economic-safety indicators was monitored.

Equimolar raw material input $\left(10 \mathrm{kmol} \mathrm{h}^{-1}\right.$ of both $\mathrm{AA}$ and $\left.\mathrm{EtOH}\right)$; inlet and outlet streams temperature of $25^{\circ} \mathrm{C}$; and atmospheric pressure were set as initial input specifications. Production of $10 \mathrm{kmol} \mathrm{h}^{-1}$ of pure ethyl acetate $(99.9 \mathrm{~mol} \%$ ), full EtAc recovery and total conversion of reactants (EtOH and AA) were targeted as design specifications. Additionally, separation of pure water (esterification reaction by-product) was considered. The process and equipment parameters were optimized while maintaining all the abovementioned design specifications fixed. Optimization was based on vapor flows minimizing in the individual columns.

\section{Simulation Results}

In general, when adjusting a distillation column model to using a mechanical vapor recompression heat pump, the column condenser is removed, a compressor, an overhead vapor flash separator and throttle valve are added, and the column reboiler is modified to use overheated column vapor as heating medium (Figure 1b). The presence of an MVRHP can change the flows in the system and changing the column dimensions is sometimes necessary.

\subsection{MVRHP in Conventional Process}

The conventional ethyl acetate production process, described in detail in our previous work [5], is depicted in Figure 2. This set-up consists of five key equipment units. Esterification reaction proceeds in a CSTR reactor, which is followed by an azeotropic distillation column, decanter and two conventional columns. For better illustration, a material balance is presented in Appendix B, Table A1. A column separating pure ethyl acetate was selected for MVRHP implementation (column C2 in Figure 2). The column feed (stream 14 in Figure 2) was composed of ethyl acetate, ethanol and water. Molar flow of the bottom product was $20 \mathrm{kmol} \mathrm{h}^{-1}\left(1.76 \mathrm{t} \mathrm{h}^{-1}\right)$ of pure EtAc (stream 17 in Figure 2). The stream 17 was divided: $10 \mathrm{kmol} \mathrm{h}^{-1}$ as a final product (stream 19 in Figure 2) and $10 \mathrm{kmol} \mathrm{h}^{-1}$ as an azeotropic distillation entrainer (stream 18 in Figure 2-recirculated back to the azeotropic distillation column C1). Molar flow of distillate was $21.21 \mathrm{kmol} \mathrm{h}^{-1}\left(1.28 \mathrm{t} \mathrm{h}^{-1}\right)$ of nearly azeotropic mixture of EtAc-EtOH- $\mathrm{H}_{2} \mathrm{O}$ (stream 15 in Figure 2). Despite relatively small product flows, column internal vapor and liquid flows were large due to the reflux ratio $(R=5)$ caused by the separation requirements. Consequently, packed column with internal diameter of $1.2 \mathrm{~m}$ and the total of two packing sections height of $3.5 \mathrm{~m}$ was used. The column packing approach to flood was less than $60 \%$ [5]. Thus, there is a possibility of further increasing the flow rates in the column without compromising its functionality, which is important when designing an MVRHP for an existing column.

Modified conventional ethyl acetate production process with an MVRHP is depicted in Figure 4. Column C2 was adapted; column condenser removed; compressor K1, flash separators C2-1 and C2-2, throttle valve VLV1, and cooler EX9 were added; column reboiler EX8 was modified. Column C2 tower is the same whether it is in conventional process without (Figure 2) or with an MVRHP (Figure 4). All other equipment (azeotropic dis- 
tillation column C1, CSTR, distillation column C3, decanter C4, heat exchangers) were unchanged. The identical part of material balance of the conventional process (Figure 2) and the conventional process with an MVRHP (Figure 4) is presented in Appendix B, Table A1. Material balance of the designed MVRHP subsystem (column C2 environment in Figure 4) is presented in Appendix B, Table A2.

Compressor K1 discharge pressure is the key design parameter of the MVRHP. Various compressor discharge pressures were tested. Lower bound was determined through minimal reboiler (EX8 in Figure 4) temperature. Temperature difference between liquid at boiling point from the column C2 bottom (stream 34 in Figure 4) and condensing temperature of overheated vapors from compressor K1 (stream 39 in Figure 4) has to be at least $10^{\circ} \mathrm{C}$. Consequently, minimal compressor $\mathrm{K} 1$ discharge pressure is $158 \mathrm{kPa}$ when the column is operated at atmospheric pressure. Discharge pressure equivalent to compression ratio of 3 was assumed as the upper bound. In addition, higher discharge pressure values are not suitable as film boiling can occur in the column reboiler. The final choice of compressor outlet pressure was based on achieving appropriate flow rates through the column (using an existing column adapted from our previous work [5] was assumed) and sufficient reboiler heat flux to ensure separation quality as required. Then, the MVRHP subsystem pressure was selected to be $250 \mathrm{kPa}$. The effect of MVRPH on various vapor flows in column $\mathrm{C} 2$ is demonstrated in Figure 5 showing that column flow rates increased by $10 \%$ approximately. However, no higher approach to flood than $82 \%$ was observed. Therefore, the MVRHP can be applied effectively in an existing column designed with some margin considering process intensification.

Energetic aspects of involving an MVRHP are discussed in Section 4.1 in more details.

\subsection{MVRHP in RD Column with a Separation Unit}

The ethyl acetate production process based on reactive distillation column with a separation unit is depicted in Figure 3. This set-up consists of a reactive distillation column, decanter and two conventional columns. For better illustration, a material balance is presented in Appendix B, Table A3. Even in this case, a column separating pure ethyl acetate was selected for MVRHP implementation (column C2 in Figure 3). Column C2 was operated similarly as that in the conventional process (column C2 in Figure 2) with its feed (stream 5 in Figure 3) composed of ethyl acetate, ethanol, and water. Molar flow of the bottom product was $10 \mathrm{kmol} \mathrm{h}^{-1}\left(0.88 \mathrm{t} \mathrm{h}^{-1}\right)$ of pure EtAc (stream 11 in Figure 3) and that of the distillate was $30.59 \mathrm{kmol} \mathrm{h}^{-1}\left(1.85 \mathrm{t} \mathrm{h}^{-1}\right)$ of nearly azeotropic mixture of EtAc-EtOH- $\mathrm{H}_{2} \mathrm{O}$ (stream 6 in Figure 3). The $\mathrm{C} 2$ column internal vapor and liquid flows were large due to the separation requirements. Consequently, vapor flows were 1.4 time higher than those in column C2 in Figure 2; column diameter was increased to $1.3 \mathrm{~m}$. Accordingly, reasonable column hydraulics were achieved (approach to flood less than $65 \%$ ) [5]. Therefore, an MVRHP can be used directly in this column (Figure 3). 


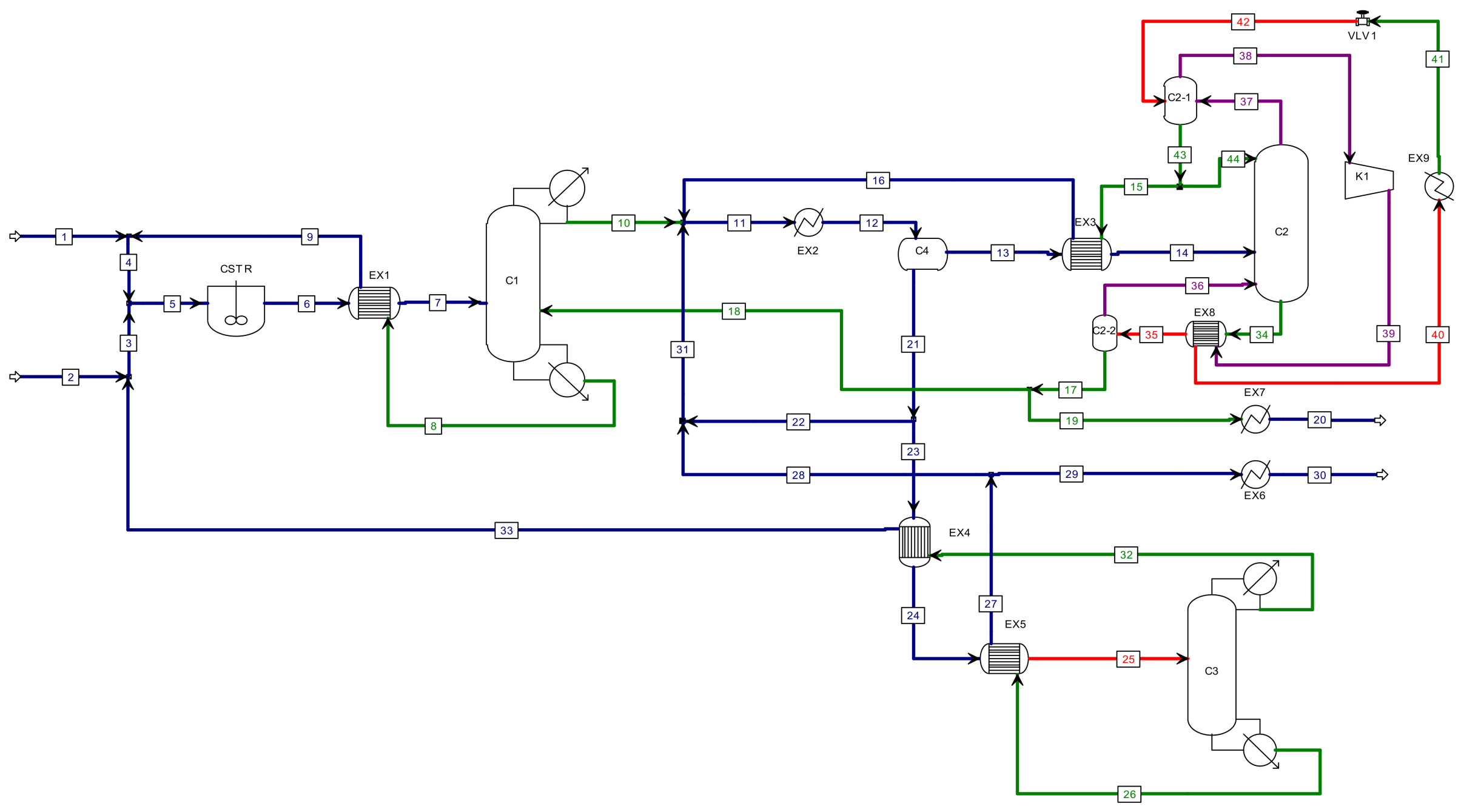

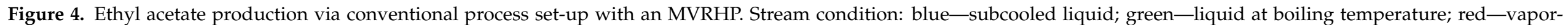

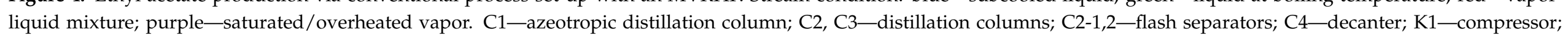
CSTR—continuous stirred tank reactor; EX1-9-heat exchangers; VLV1—-throttle valve. 


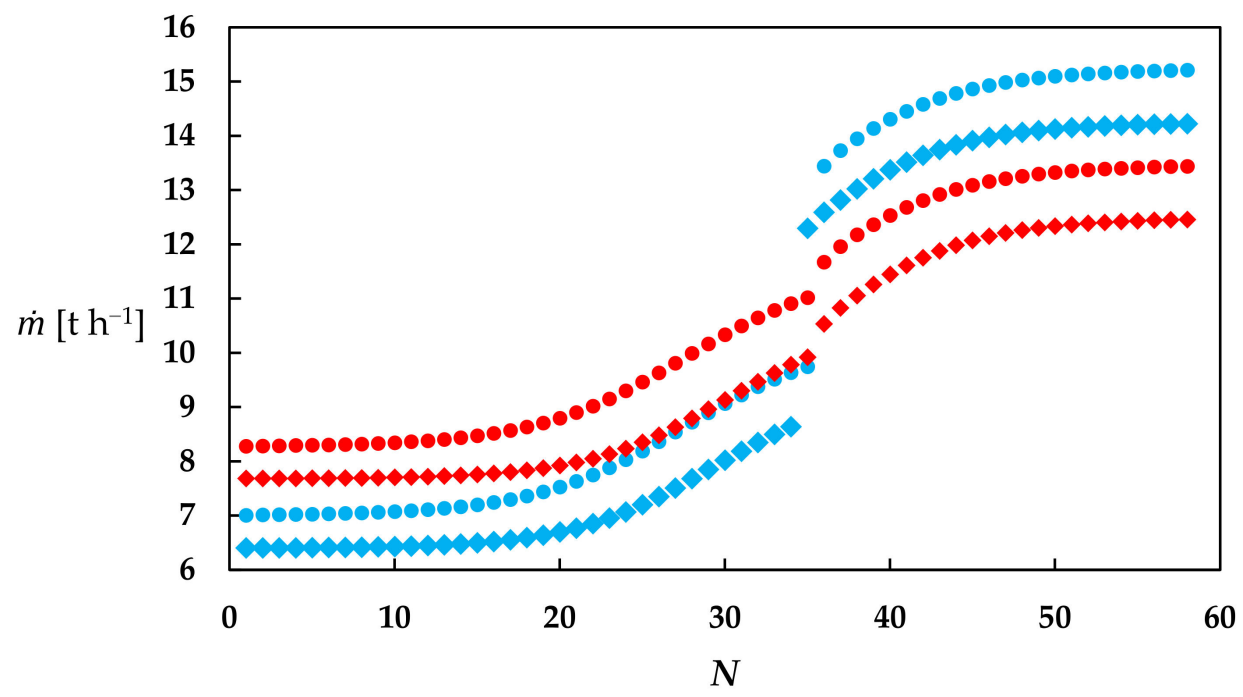

Figure 5. Ethyl acetate separation column flow rate profiles; diamonds-conventional process (column C2 in Figure 2); circles-conventional process with an MVRHP (column C2 in Figure 4); blue-liquid flow; red-vapor flow.

A modified reactive distillation column with a separation unit and an MVRHP is depicted in Figure 6. Column C2 was modified similarly as described in Section 3.1. All other equipment (reactive distillation column C1-RD, distillation column C3, tower of distillation column $\mathrm{C} 2$, decanter $\mathrm{C} 4$, heat exchangers) were unchanged compared to the configuration in Figure 3. The MVRPH subsystem in Figure 6 is composed of compressor K1, flash separators C2-1 and C2-2, cooler EX7, reboiler EX6 and throttle valve VLV1. The mass balance of the RD column with a separation unit and an MVRHP (Figure 6) is presented in Appendix B, Table A2. The part identical with the RD column with a separation unit (Figure 3) is presented in Appendix B, Table A3. The MVRHP subsystem (column C2 environment in Figure 6) material balance is provided in Appendix B, Table A4.

Compressor K1 (Figure 6) discharge pressure is the key design parameter of the MVRHP same as in the case of the conventional process with an MVRHP (Figure 4). The MVRHP operating parameters (discharge pressure, reboiler temperature difference, flow rates) were designed in the same way as described in Section 3.1. Similar results were obtained due to the similar column operation conditions and specifications (product purity). Consequently, the compressor discharge pressure was set to $250 \mathrm{kPa}$. Due to the inclusion of a heat pump, flow rates in column C2 in Figure 6 increased by $6 \%$ approximately compared to column $\mathrm{C} 2$ in Figure 4. An approach to flood of $78 \%$ is reached.

Effect of the MVRHP on energetic aspects is discussed in Section 4.1 in more details. 


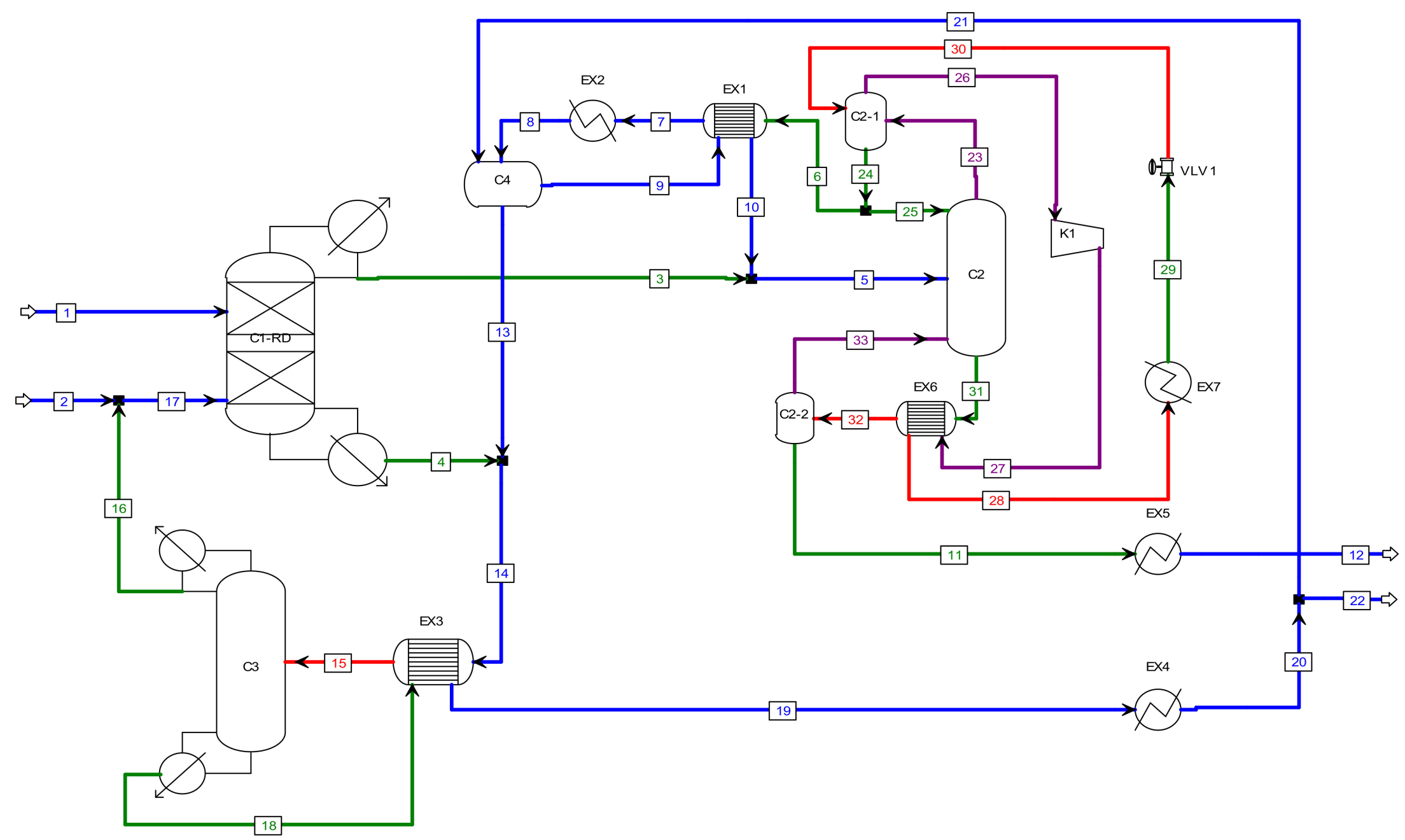

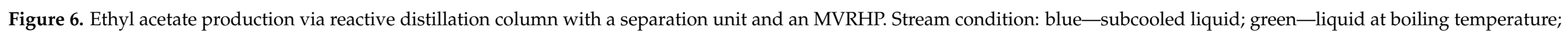

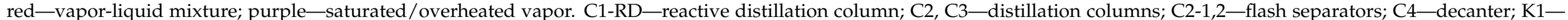
compressor; EX1-7-heat exchangers; VLV1—throttle valve. 


\section{Discussion}

\subsection{Heat Pump Effect on Process Energy Intensity}

Energy consumption of individual equipment units for four processes (conventional process-Figure 2, RD column with a separation unit-Figure 3, conventional process with an MVRHP-Figure 4 and RD column with a separation unit and an MVRHP—Figure 6) were calculated based on the simulation results. Reboiler duty $\left(\dot{Q}_{W}\right)$, condenser duty $\left(\dot{Q}_{C}\right)$, compressor required network $(W)$ and cooling duty of heat exchangers including heat integration were evaluated. The sum of required heating or cooling duties, except for heat integration and compressor network, is included in overall energy consumption (OEC) which is normalized to the specific energy consumption (SEC) related to the production of one ton of pure EtAc. A detailed summary of energy requirements is listed in Table 3.

Significant changes of heating and cooling demands occurred when using the MVRHP (Table 3). The changes can be divided into three parts: MVRHP efficiency assessment; heating demands—column reboiler, and cooling demands—column condenser.

The MVRHP potential in energy saving is assessed by COP and PES. COP is calculated by Equation (1). The heat required by the corresponding distillation column (column C2 in the conventional process or $\mathrm{C} 2$ in the RD column with a separation unit, respectively); electric work required by the compressor (K1 in the conventional process with an MVRHP or K1 in the RD column with a separation unit and an MVRHP) were taken from Table 3. Primary energy savings (PES) were calculated by Equation (2). Natural gas was assumed to be the primary source for both reference efficiency of electricity $\left(\eta_{E}\right)$ and heat $\left(\eta_{Q}\right)$ production; $\eta_{E}=0.525 ; \eta_{Q}=0.90$ [33]; the results are listed in Table 4. As described in Section 1.4.1, if COP is higher than 5, the MVRHP application is recommended. Moreover, PES of up to $80 \%$ are achieved in both designed MVRHPs. Consequently, evaluated indicators show that the designed MVRHP is suitable in both the conventional process (Figure 4) as well as the RD column with a separation unit (Figure 6).

When using an MVRHP, a change of the heating medium is required: steam is replaced by compressed overheated vapor as the heating medium for the distillation column C2 reboiler (EX8 in Figure 4 and EX6 in Figure 6). Therefore, it is necessary to adjust the reboiler of column $\mathrm{C} 2$. The heat exchange area $(A)$ of the reboiler is increased as the overall heat transfer coefficient decreases in case of using overheated vapors instead of steam. Another important parameter affecting the required reboiler heat exchange area is compressor discharge pressure. Overheated vapor temperature and its total flow are dependent on the compressor discharge pressure. Consequently, the required heat exchange area changes according to the overheated vapor energy content, as depicted in Figure 7.

Increasing the compressor discharge pressure leads to rapid decrease in $A$. However, as it is explained in Section 3.1, a reasonable value of the compressor discharge pressure is $250 \mathrm{kPa}$. Fortunately, as shown in Figure 7, if discharge pressure is increased above $250 \mathrm{kPa}$, only small reduction in $A$ is achieved. Consequently, the column $\mathrm{C} 2$ reboiler heat transfer area increased from $24.0 \mathrm{~m}^{2}$ (conventional process in Figure 2) to $88.4 \mathrm{~m}^{2}$ (conventional process with an MVRHP in Figure 4). In case of RD column with a separation unit (Figure 3), the column C2 reboiler heat transfer area increased from $33.2 \mathrm{~m}^{2}$ to $114.6 \mathrm{~m}^{2}$ (RD column with a separation unit and an MVRHP in Figure 6). 
Table 3. Energy requirements and the number of equipment units for designed ethyl acetate production pathways.

\begin{tabular}{|c|c|c|c|c|c|c|c|c|}
\hline \multirow{2}{*}{ Equipment } & \multirow{2}{*}{\multicolumn{2}{|c|}{$\begin{array}{c}\text { Conventional Process } \\
\text { (Figure 2) }\end{array}$}} & \multirow{2}{*}{\multicolumn{2}{|c|}{$\begin{array}{c}\text { Conventional Process with an MVRHP } \\
\text { (Figure 4) }\end{array}$}} & \multirow{2}{*}{\multicolumn{2}{|c|}{$\begin{array}{c}\text { RD Column with a Separation Unit } \\
\text { (Figure } 3 \text { ) }\end{array}$}} & \multirow{2}{*}{\multicolumn{2}{|c|}{$\begin{array}{l}\text { RD Column with a Separation } \\
\text { Unit and an MVRHP } \\
\text { (Figure 6) }\end{array}$}} \\
\hline & & & & & & & & \\
\hline C1/C1-RD & 1135.23 & 1181.19 & 1135.23 & 1181.19 & 676.69 & 703.86 & 676.69 & 703.86 \\
\hline $\mathrm{C} 2$ & 1212.97 & 1267.94 & - & - & 1750.31 & 1759.95 & - & - \\
\hline K1 & - & - & - & $151.67^{c}$ & - & - & - & $197.34^{c}$ \\
\hline $\mathrm{C} 3$ & 502.97 & 549.35 & 502.97 & 549.35 & 323.10 & 361.93 & 323.10 & 361.93 \\
\hline C4 & 0.85 & - & 0.85 & - & 8.07 & - & 8.07 & - \\
\hline EX1 & $25.01^{a}$ & - & $25.01^{a}$ & - & $31.04^{a}$ & - & $31.04^{a}$ & - \\
\hline EX2 & 133.75 & - & 133.75 & - & 28.61 & - & 28.61 & - \\
\hline EX3 & $31.04^{a}$ & - & $33.81^{a}$ & - & $77.70^{a}$ & - & $77.70^{a}$ & - \\
\hline EX4 & $13.73^{a}$ & - & $13.73^{a}$ & - & 27.83 & - & 27.83 & - \\
\hline EX5 & $131.31^{a}$ & - & $131.31^{a}$ & - & 25.89 & - & 25.89 & - \\
\hline EX6 & 3.10 & - & 3.10 & - & - & - & - & $\mathbf{1 7 6 3 . 8 8}^{a, b}$ \\
\hline EX7 & 25.85 & - & 25.85 & - & - & - & 154.48 & - \\
\hline EX8 & - & - & - & $1359.33^{a, b}$ & - & - & - & - \\
\hline SEC $\left[\mathrm{kWh} \mathrm{t}^{-1}{ }_{\text {EtAc }}\right]$ & 3424.69 & 3406.24 & 2139.06 & 1965.88 & 3226.77 & 3210.01 & 1413.93 & 1210.73 \\
\hline Number of main equipment units & \multicolumn{2}{|c|}{5} & \multicolumn{2}{|c|}{$5+\mathrm{K} 1$} & \multicolumn{2}{|c|}{4} & \multicolumn{2}{|c|}{$4+\mathrm{K} 1$} \\
\hline Number of heat exchangers & \multicolumn{2}{|c|}{7} & \multicolumn{2}{|c|}{9} & \multicolumn{2}{|c|}{5} & \multicolumn{2}{|c|}{7} \\
\hline
\end{tabular}

${ }^{a}$ heat integration—no external energy source is required, ${ }^{b}$ column C2 reboiler-heat pump, ${ }^{c}$ compressor network required. 
Table 4. Efficiency indicators of designed MVRHP.

\begin{tabular}{ccc}
\hline & $\begin{array}{c}\text { Conventional Process with } \\
\text { an MVRHP (Figure 4) }\end{array}$ & $\begin{array}{c}\text { RD Column with a Separation Unit and } \\
\text { an MVRHP (Figure 6) }\end{array}$ \\
\hline COP & 8.36 & 8.92 \\
PES [\%] & 79.49 & 80.78 \\
\hline
\end{tabular}

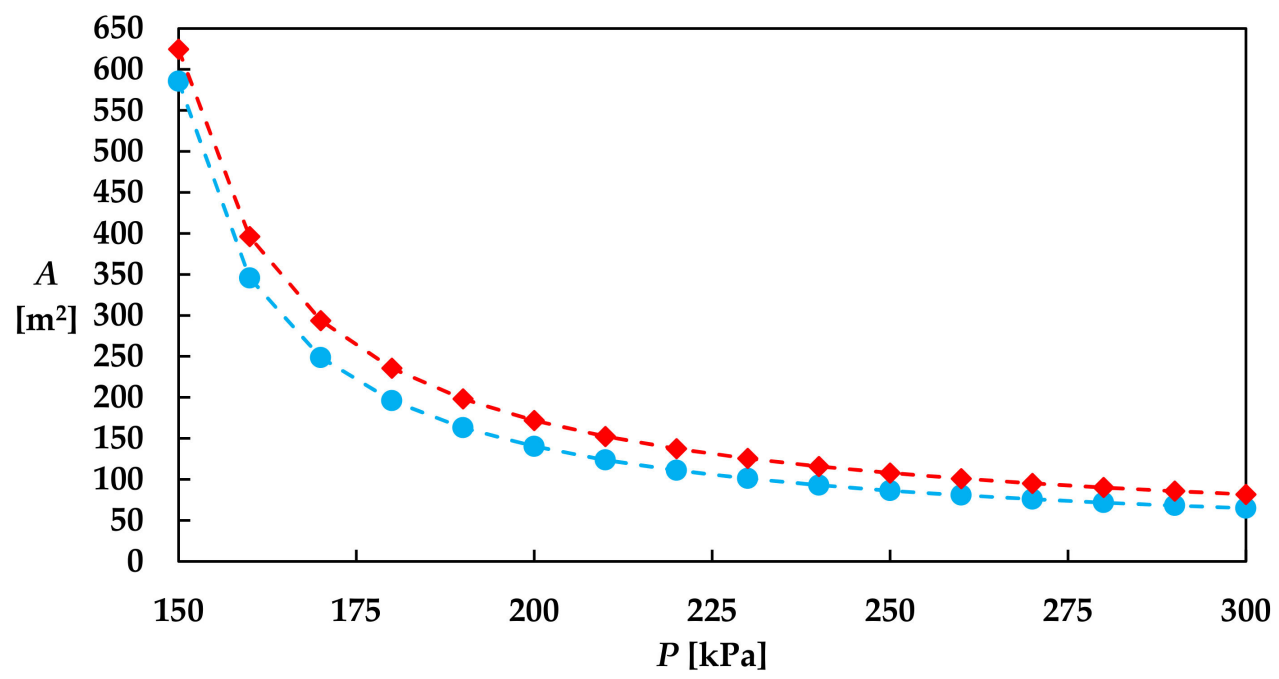

Figure 7. Effect of compressor discharge pressure on the required column reboiler heat exchanger area; blue circles - conventional process with an MVRHP (Figure 4), red diamond-RD with a separation unit and an MVRHP (Figure 6).

Despite the increase in the reboiler heat transfer area, the main benefit of the MVRHP concept is reflected in the reduction in external heat duty required. The conventional process (Figure 2) requires heat duty of $2998.48 \mathrm{~kW}$; the conventional process with an MVRHP (Figure 4) requires heat duty of $1730.54 \mathrm{~kW}$ and compressor network of $151.67 \mathrm{~kW}$ (Table 3). Thus, energy savings of up to $42.3 \%$ just in heating demands can be achieved when an MVRHP is used. The RD column with a separation unit (Figure 3) requires heat duty of $2825.74 \mathrm{~kW}$, while the RD column with a separation unit and an MVRHP (Figure 6) requires heating duty of $1065.79 \mathrm{~kW}$ and compressor network of $197.34 \mathrm{~kW}$ (Table 3). Thus, heating demands can be decreased by up to $62.3 \%$ as it is depicted in Figure 8 . The compressor network consumption is reflected in increased electricity consumption, which is evaluated within the process economics in Section 4.2.

A large column condenser is not needed when using an MVRHP (Figure 1b) and only a small air cooler is used to remove waste heat (heat exchanger EX9 in the conventional process with an MVRHP in Figure 4; heat exchanger EX7 in the RD column with a separation unit and an MVRHP in Figure 6. Cooling duty of air cooler EX9 is only $6.7 \%$ compared to the condenser of column C2 in the conventional process (Table 3) and of air cooler EX7 it is only $8.9 \%$ compared to the condenser of column C2 in the RD column with a separation unit (Table 3). Consequently, large amount of cooling duty can be saved. When using an MVRHP, cooling duty savings of up to $37.5 \%$ (conventional process with an MVRHP in Figure 4) and up to 56.2\% (RD column with a separation unit with an MVRHP in Figure 6) can be achieved. The MVRHP effect on overall cooling duty is depicted in Figure 8. 


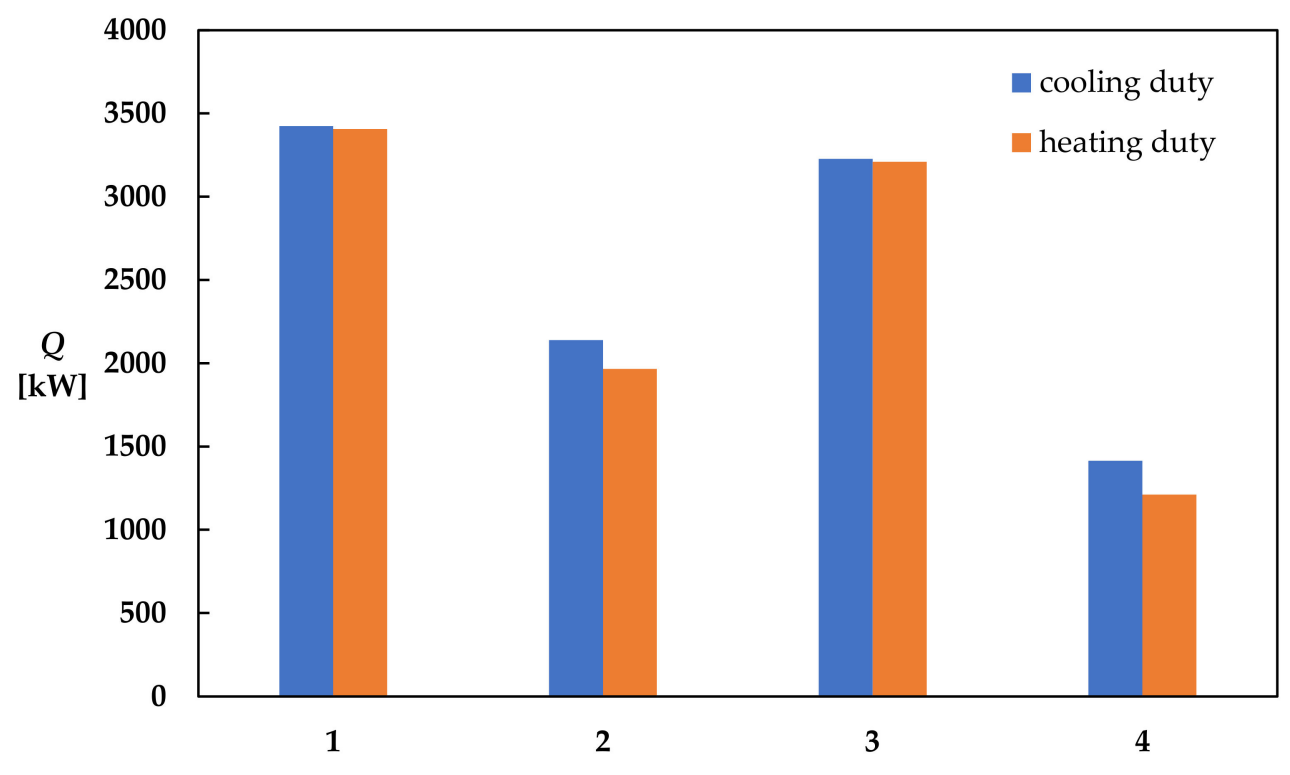

Figure 8. MVRHP effect on overall energy requirements; 1 -conventional process (Figure 2), 2-conventional process with an MVRHP (Figure 4), 3-RD column with a separation unit (Figure 3), 4-RD column with a separation unit and an MVRHP (Figure 6).

\subsection{Heat pump Effect on Process Economics}

Economic evaluation of the designed processes was based on optimized simulations results presented in Sections 3 and 4.1. Commodity prices were selected according to market survey [44-46]. Prices of reactants and product were chosen as a long-term average. Energy utilities (electricity, cooling water and steam) costs were obtained from Aspen Plus database [39]. These utility costs correspond with actual prices including taxes and emission charges [47]. A summary of all prices is listed in Table 5.

Table 5. Prices of raw materials, products, and energy used in economic evaluation.

\begin{tabular}{|c|c|c|c|}
\hline Raw Materials & & & References \\
\hline $\mathrm{EtOH}$ & 800 & USD $t^{1}$ & {$[44,45]$} \\
\hline AA & 400 & $\mathrm{USD}^{-1}$ & {$[44]$} \\
\hline \multicolumn{4}{|l|}{ Products } \\
\hline EtAc & 1300 & USD $t^{1}$ & [46] \\
\hline Energy & & & {$[39,47]$} \\
\hline Electricity & 0.0775 & $\mathrm{USD}_{\mathrm{kWh}}{ }^{-1}$ & \\
\hline Cooling water & 0.0317 & $\mathrm{USD}^{-3}$ & \\
\hline Steam (0.7 MPa) & 0.0179 & $\mathrm{USD} \mathrm{kg}^{-1}$ & \\
\hline
\end{tabular}

Equipment cost, except for compressor, was calculated by the Aspen Plus Economic Analyzer software [39]. As rate-based modeling was applied, equipment dimensions and set-up are known. Also, special column configuration, distillation column with an MVRHP, has been introduced. Consequently, individual mapping and sizing of each equipment unit was done. The compressor cost was estimated by the index method recommended by Chemical Process Equipment Selection and Design [43]. Detailed individual equipment cost as well as installed cost are listed in Appendix B, Table A5. When an MVRHP was used, the total equipment cost increased compared to processes without HP by $11.4 \%$ in case of conventional process with an MVRHP (Figure 4), by 13.5\% in case of RD column with a separation unit and an MVRHP (Figure 6). The trend is shown in Figure 9. 
Utilities consumption was calculated based on energy requirements of individual ethyl acetate production pathways (Table 3). Subsequently, utility rate and cost on hourly basis were calculated and the results are listed in Table 6. The MVRHP effect on total utility cost (mil. USD year ${ }^{-1}$ ) trend is depicted in Figure 9.

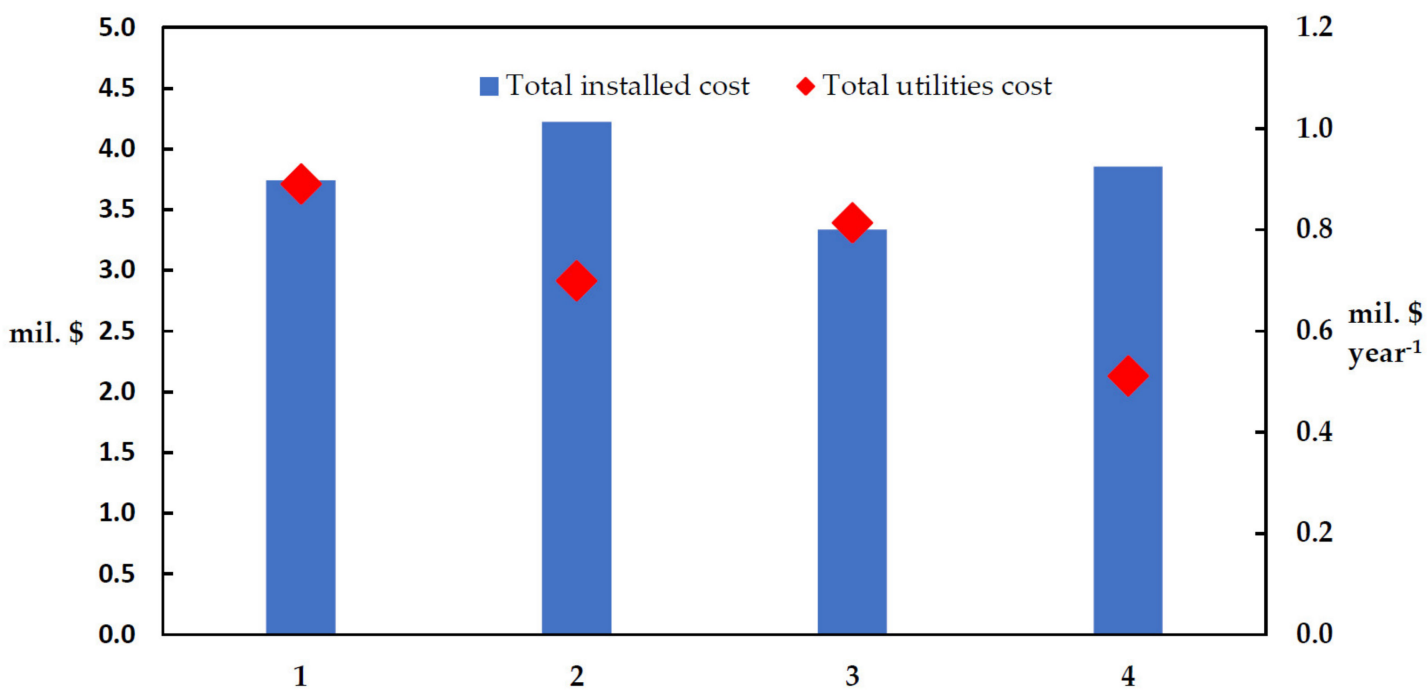

Figure 9. MVRHP effect on total equipment cost and total utility cost; 1 -conventional process (Figure 2), 2-conventional process with an MVRHP (Figure 4), 3-RD column with a separation unit (Figure 3), 4-RD column with a separation unit and an MVRHP (Figure 6).

The conventional process (Figure 2) is the most energy-intensive, which is reflected in steam and cooling water consumption. The steam consumption is $5.2 \mathrm{th}^{-1}$; cooling water consumption is $233 \mathrm{~m}^{3} \mathrm{~h}^{-1}$ and electricity consumption is $104 \mathrm{~kW}$. When an MVRHP is used in the conventional process (Figure 4), the steam consumption decreases by $42.3 \%$, and cooling water consumption decreases by $40.2 \%$; however, electricity consumption increases 3.4 times. This is caused by the inclusion of a compressor as steam consumption is replaced by electricity. Based on utility prices listed in Table 5 , hourly cost for all consumed energy decreases by $21.5 \%$ when an MVRHP is used in the conventional process (Figure 4).

An RD column with a separation unit (Figure 3) is slightly less energy-intensive compared to the conventional process (Figure 2) because of process integration and intensification via reactive distillation. Consequently, when an MVRHP is used in the RD column with a separation unit (Figure 6), the followings saving compared to the original RD column with a separation unit (Figure 3) are achieved: steam consumption decreases by $62.3 \%$; cooling water consumption decreases by $61.6 \%$, but electricity consumption increases 5.9 times. Finally, hourly price rate for consumed energy decreases by $37.1 \%$. Detailed numbers are presented in Table 6; the trend is depicted in Figure 9.

As it can be seen from Table 6 and Figure 9, the MVRHP configuration reduces the energy consumption significantly, which has a direct positive effect on the environment as well as the amount of greenhouse gases produced. However, in case of $\mathrm{CO}_{2}$ emissions, a compressor can produce much more $\mathrm{CO}_{2}$ emissions than a reboiler with the same energy consumption $(\mathrm{kW})$. Therefore, $\mathrm{CO}_{2}$ emission estimation was included in the presented work. In the $\mathrm{CO}_{2}$ emission estimation model used electricity was assumed to be imported to the plant from the electricity producer and distributor. Heat $(0.7 \mathrm{MPa}$ steam) is produced directly at the plant. To generate saturated steam, a steam boiler with the overall efficiency of $93.5 \%$ was used. The composition of natural gas and its physical properties were adopted from the main natural gas distributor-SPP, a.s. The amount of natural burnt was estimated using material and energy balances. The $\mathrm{CO} 2$ emission factor used in the estimation was $55.68 \mathrm{~kg}_{\mathrm{CO} 2} \mathrm{GJ}^{-1}$, calorific value was $34.89 \mathrm{MJ} \mathrm{m}^{-3}$ and the oxidation 
factor was assumed to be 1 . Total $\mathrm{CO}_{2}$ emissions were estimated by multiplying fuel consumption by an emission factor, net calorific value and an oxidation factor. The average $\mathrm{CO}_{2}$ emission factor of electricity generation was adopted from information provided by the Ministry of Environment of the Slovak Republic. The value of emission factor is $166.87 \mathrm{~kg} \mathrm{MWh}^{-1}$, which is slightly lower than European Union average (due to high share of nuclear to total energy consumption in electricity generation in the Slovak Republic). The $\mathrm{CO}_{2}$ emissions were estimated based on multiplication of electricity consumption and the $\mathrm{CO}_{2}$ emission factor.

The calculated $\mathrm{CO}_{2}$ emissions are conventional process (Figure 2)—6974.3 $\mathrm{t} \mathrm{year}^{-1}$, conventional process with an MVRHP (Figure 4) - $4421.9 \mathrm{t}_{\text {year }}{ }^{-1}$, RD column with a separation unit (Figure 3)-6519.8 t year $^{-1}$, and an RD column with a separation unit and an MVRHP (Figure 6) - 2899.2 $\mathrm{t} \mathrm{year}^{-1}$. From the above values follows that the presence of MVRHP (conventional process with an MVRHP in Figure 4, RD column with a separation unit and an MVRHP in Figure 6), significantly reduces $\mathrm{CO}_{2}$ emissions compared to the original processes (conventional process with an MVRHP in comparison with conventional process, $\mathrm{CO}_{2}$ production was reduced by around $37 \%$; $\mathrm{RD}$ column with a separation unit and an MVRHP in comparison with RD column with a separation unit, $\mathrm{CO}_{2}$ production was reduced by around $56 \%$ ).

The presented $\mathrm{CO}_{2}$ emission estimation is illustrative, and it was used to compare $\mathrm{CO}_{2}$ production by alternative processes. There are several possibilities of reducing $\mathrm{CO}_{2}$ emissions and of optimizing the process of combined heat and electricity production and/or replacing fossil fuels with biomass.

To complete the economic analysis, total capital costs, total annual costs, total raw material costs, and product sales were calculated. An annual work fund of 340 days and a return rate of $20 \%$ per year were assumed. Total raw materials cost $\left(5.46\right.$ mil. USD year $\left.^{-1}\right)$ and total product sales (10.27 mil. USD year ${ }^{-1}$ ) are identical for all four compared pathways and the results are summarized in Table 7. When an MVRHP is present (conventional process with an MVRHP in Figure 4, RD column with a separation unit and an MVRHP in Figure 6), the capital costs increase by around 12\% compared to the original processes (conventional process in Figure 2, RD column with a separation unit in Figure 3). On the other hand, the total annual costs decrease due to the MVRHP implementation as processes energy requirements decrease (explained in Section 4.1).

Finally, a simple payback period was calculated: an initial two year-period of project feasibility and preparation (projecting, building, licensing, etc.) was included. When using an MVRHP, the simple payback period is reduced by approximately one year in both conventional process and RD column with a separation unit.

\subsection{Heat Pump Effect on Chemical Process Safety}

Overall safety analysis in this work is based on the Chemical Process Quantitative Risk Analysis. To evaluate and compare safety aspects of the presented alternatives, individual risk estimation was performed for each presented case study. For each type of units, a predefined set of representative incidents was prepared. The final choice of incidents is complex and requires judgment from an analyst; therefore, three main factors were taken into consideration: size of the release, state of released material (liquid, vapor) and character of the release (instantaneous or continuous-more detail in [5]). Fault tree probabilities were adjusted based on recommendation from [48]. Consequence modeling was performed using standard (and widely used) software system ALOHA (The Areal Location of Hazardous Atmospheres) provided by the US Environmental Protection Agency. Probabilities of individual representative atmospheric conditions were adopted from data provided by the Slovak Hydrometeorological Institute. 
Table 6. Comparison of utility consumption: originally designed processes and processes using MVRHP.

\begin{tabular}{|c|c|c|c|c|c|c|c|c|}
\hline & \multirow{2}{*}{\multicolumn{2}{|c|}{$\begin{array}{c}\text { Conventional Process } \\
\text { (Figure 2) }\end{array}$}} & \multirow{2}{*}{\multicolumn{2}{|c|}{$\begin{array}{c}\text { Conventional Process with an MVRHP } \\
\text { (Figure } 4)\end{array}$}} & \multirow{2}{*}{\multicolumn{2}{|c|}{$\begin{array}{c}\text { RD Column with a Separation Unit } \\
\text { (Figure 3) }\end{array}$}} & \multirow{2}{*}{\multicolumn{2}{|c|}{$\begin{array}{c}\begin{array}{c}\text { RD column with a Separation Unit } \\
\text { and an MVRHP }\end{array} \\
\text { (Figure 6) }\end{array}$}} \\
\hline & & & & & & & & \\
\hline & Rate & $\begin{array}{c}\text { Price } \\
\text { [USD h } h^{-1} \text { ] }\end{array}$ & Rate & $\begin{array}{c}\text { Price } \\
{\left[\text { USD h } h^{-1} \text { ] }\right.}\end{array}$ & Rate & $\begin{array}{c}\text { Price } \\
{\left[\text { USD h } h^{-1} \text { ] }\right.}\end{array}$ & Rate & $\begin{array}{c}\text { Price } \\
{\left[\mathrm{USD} \mathrm{h}^{-1} \text { ] }\right.}\end{array}$ \\
\hline Electricity $[\mathrm{kW}]$ & 104.2 & 8.1 & 351.5 & 27.2 & 58.1 & 4.5 & 345.1 & 26.8 \\
\hline Cooling water $\left[\mathrm{m}^{3} \mathrm{~h}^{-1}\right]$ & 233.1 & 7.4 & 139.3 & 4.4 & 219.4 & 7.0 & 85.0 & 2.7 \\
\hline Steam (0.7 MPa) $\left[\mathrm{kg} \mathrm{h}^{-1}\right]$ & 5220.0 & 93.7 & 3012.7 & 54.1 & 4920.7 & 88.3 & 1856.0 & 33.3 \\
\hline
\end{tabular}

Table 7. MVRHP effect on total annual costs of designed processes.

\begin{tabular}{|c|c|c|c|c|}
\hline & Conventional Process & $\begin{array}{l}\text { Conventional Process } \\
\text { with an MVRHP }\end{array}$ & $\begin{array}{l}\text { RD Column with a } \\
\text { Separation Unit }\end{array}$ & $\begin{array}{l}\text { RD Column with a Separation } \\
\text { Unit and an MVRHP }\end{array}$ \\
\hline & (Figure 2) & (Figure 4) & (Figure 3) & (Figure 6) \\
\hline Total capital cost [mil. USD] & 9.91 & 11.19 & 8.84 & 10.21 \\
\hline Total installed cost [mil. USD] & 3.74 & 4.22 & 3.33 & 3.85 \\
\hline Total annual cost [mil. USD year ${ }^{-1}$ ] & 9.15 & 8.88 & 9.04 & 8.61 \\
\hline Total raw materials cost [mil. USD year ${ }^{-1}$ ] & 5.46 & 5.46 & 5.46 & 5.46 \\
\hline Total product sales [mil. USD year ${ }^{-1}$ ] & 10.27 & 10.27 & 10.27 & 10.27 \\
\hline Total utilities cost [mil. USD year ${ }^{-1}$ ] & 0.89 & 0.70 & 0.81 & 0.51 \\
\hline Pay-back period [year] & 10.86 & 10.02 & 9.19 & 8.13 \\
\hline Total production cost $\left[\mathrm{USD} \mathrm{t}^{-1}\right]$ & 1273.9 & 1264.8 & 1266.1 & 1248.2 \\
\hline
\end{tabular}


Results of individual risk estimation for the presented case studies are depicted in Figure 10. To compare all investigated case studies, individual risk is presented in form of risk profiles as a function of distance. Based on the risk profiles, it is possible to conclude that, implementing an MVRHP increases the individual risk of processes. This conclusion was expected because, as MVRHP is included, the compressor, flash separators, throttle valve, cooler and increased number of pipelines have to be taken into account when preparing the set of representative incidents.

Figure 11 compares individual risk of fatality in various equipment types for a conventional process without (Figure 11a) and with (Figure 11b) an MVRHP. The increase in individual risk of fatality in processes with an MVRHP is due to the compressor (green line in Figure 11b only), higher number of heat exchangers (red lines in Figure 11), higher number of pipelines (purple lines in Figure 11), as well as the increase in the amount of saturated/overheated vapor recirculated in the system. The same conclusions would result from a comparison of the individual risk of fatality for an RD column with a separation unit without (Figure 3) and with an MVRHP (Figure 6). Considering the boundary of acceptable risk, $1 \times 10^{-5}$ year $^{-1}$ for existing plants (Table 8), the least suitable set-up is the RD column with a separator unit and an MVRHP due to high flow rates through the columns and the simultaneous MVRHP integration.

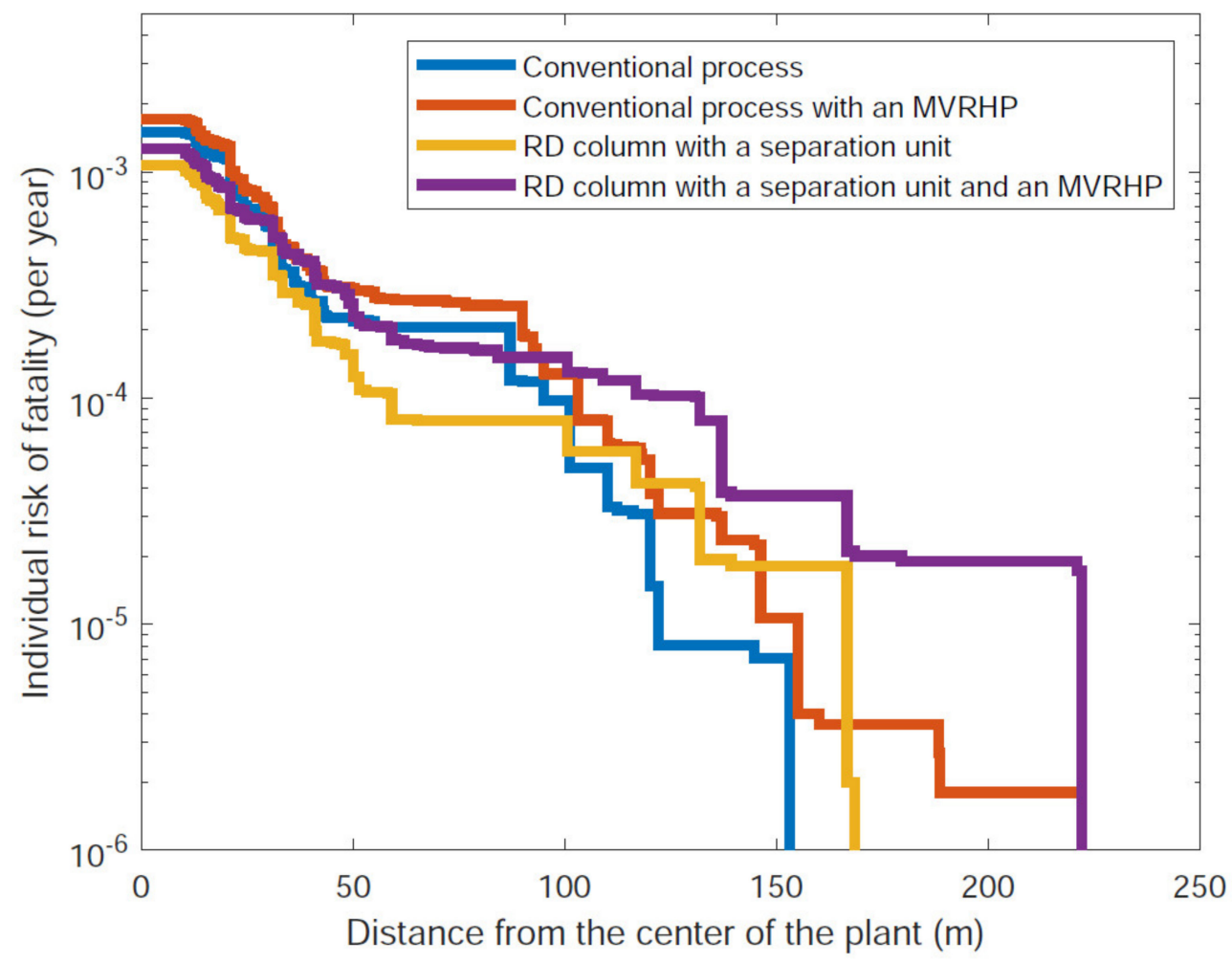

Figure 10. Individual risk of fatality estimation for presented case studies. 


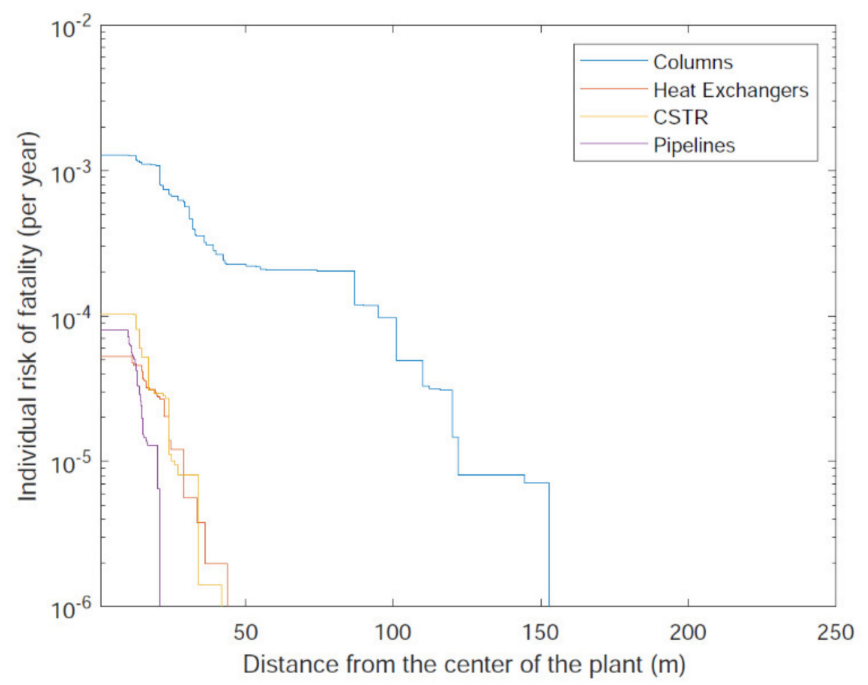

(a)

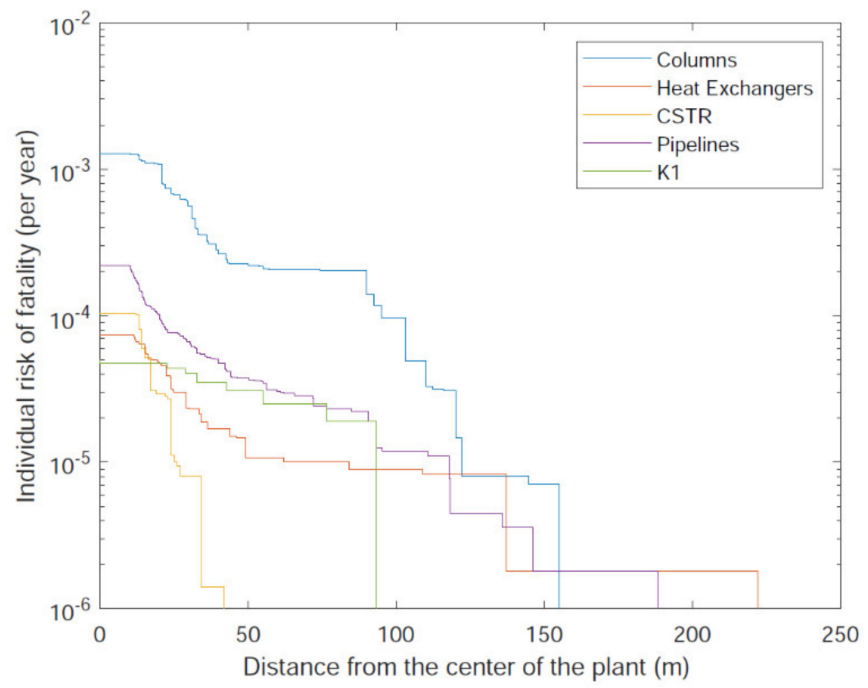

(b)

Figure 11. Individual risk of fatality grouped by equipment types: (a) conventional process (Figure 2); (b) conventional process with an MVRHP (Figure 4).

Table 8. Distance from the center of the individual case studies below which the individual risk of fatality is lower than $10^{-5}$ resp. $10^{-4}$ year $^{-1}$.

\begin{tabular}{ccc}
\hline & $\begin{array}{c}\text { Individual Risk 10 } \\
\text { Distance from the Center [m] }\end{array}$ & $\begin{array}{c}\text { Individual Risk 10 }^{-\mathbf{4}} \text { Year } \\
\text { Distance from the Center [m] }\end{array}$ \\
\hline $\begin{array}{c}\text { Conventional process (Figure 2) } \\
\text { RD column with separation unit (Figure 3) }\end{array}$ & 122 & 95 \\
$\begin{array}{c}\text { Conventional process with an MVRHP (Figure 4) } \\
\text { RD column with separation unit and an MVRHP } \\
\text { (Figure 6) }\end{array}$ & 166 & 59 \\
\hline
\end{tabular}

\subsection{Overall Heat Pump Application Assessment}

The MVRHP application benefits are clearly shown in improved process energy effectivity and economics as described in Sections 4.1 and 4.2. Despite the total capital cost increase due to process changes and compressor price, energy consumption, the total annual cost and pay-back period are reduced in both conventional process with an MVRHP (Figure 4) and RD column with separation unit and an MVRHP (Figure 6) compared to the originally designed processes (Table 7).

From the energy and economic point of view, the RD column with a separation unit and an MVRHP (Figure 6) is the best alternative for ethyl acetate production among the assessed ones (conventional process in Figure 2, conventional process with an MVRHP in Figure 4 and RD column with a separation unit in Figure 3). On the other hand, process intensification and integration using an MVRHP had serious effect on individual risk as described in Section 4.3. From the safety point of view, the RD column with a separation unit and an MVRHP (Figure 6) is the least suitable set-up because the individual risk of fatality is higher for all monitored distances from the idealized center of the plant. Nevertheless, based on the results of this work, the MVRHP application is highly recommended to improve existing ethyl acetate production processes/plants involving conventional path (Figure 2) and RD column with a separation unit (Figure 3). The RD column with a separation unit and an MVRHP (Figure 6) is preferred due to better energy and economic performance despite the higher individual risk. 
On the contrary, in case a completely new plant for ethyl acetate production is designed, using the technology of thermally coupled system represented by RDS process (Appendix A, Figure A1), presented in more detail in [5], is more appropriate. Despite the heat consumption of the thermally coupled system (RDS) of $1843 \mathrm{~kW}$ [5], which is by $42.2 \%$ higher than of the RD column with a separation unit and an MVRHP (Figure 6), no compressor network is required. The cooling duty of the RDS (Appendix A, Figure A1) was $1857.7 \mathrm{~kW}$ [5], which is by $33.0 \%$ higher than of the RD column with a separation unit and an MVRHP (Table 3). However, due to actual prices of energies (electricity, cooling water, steam) listed in Table 5, a comparable hourly price rate of consumed energy is achieved in both RDS (66.5 USD h${ }^{-1}$ [5]) and RD column with a separation unit and an MVRHP (62.7 USD $\mathrm{h}^{-1}$ in Table 6). The main advantage of the thermally coupled system compared to the RD column with a separation unit and an MVRHP is in the lower capital cost and shortened pay-back period. The total capital cost of the RDS was only 6.43 mil. USD [5] while it was 10.21 mil. USD for the RD column with a separation unit and an MVRHP (Table 7). Therefore, the thermally coupled process (RDS in Appendix A, Figure A1) can reduce the capital cost by $37.0 \%$ compared to the integrated and intensified process represented by the RD column with a separation unit and an MVRHP (Figure 6). Consequently, the payback period of the RDS was two years shorter than that of the RD column with a separation unit and an MVRHP (8.1 year in Table 7).

Moreover, the RDS process is also preferred from the safety analysis point of view. Figure 12 compares the individual risk of fatality for the RD column with a separation unit and an MVRHP (Figure 6) and RD column with a stripper column (RDS in Appendix A, Figure A1). From the comparison of individual risk of fatality estimation (Figure 12), it is clear that minimizing the number of equipment and internal recycles leads to reduction in the level of risk.

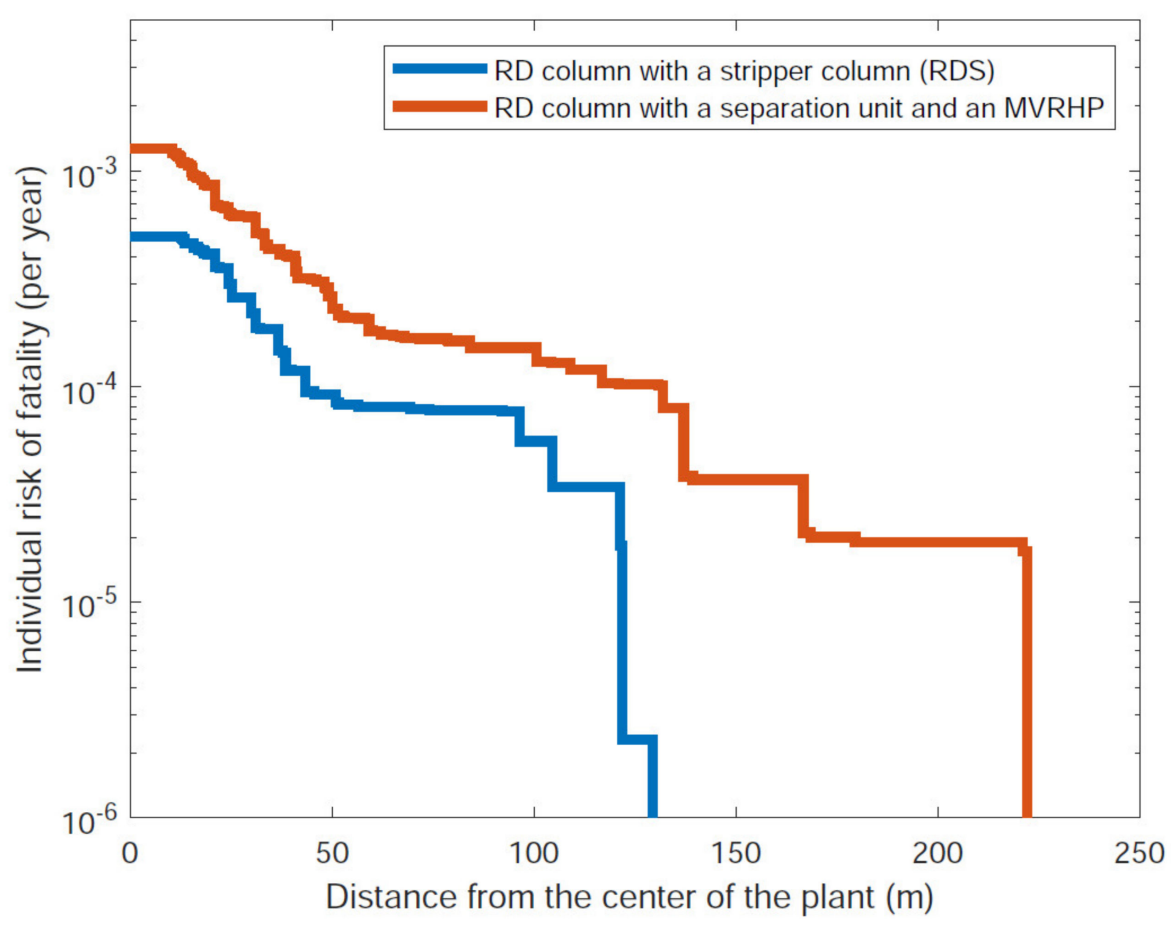

Figure 12. Individual risk of fatality estimation for RD column with a separation unit and an MVRHP (Figure 6) and RD column with a stripper column (RDS in Appendix A, Figure A1). 


\section{Conclusions}

Heat pump-assisted production of ethyl acetate has been studied. MVRHP was designed in the conventional production process (Figure 4) and in an RD column with a separation unit (Figure 6). The effect of the use of an MVRHP was evaluated by multi-objective assessment based on energy requirements, economic, and safety analysis. The results show that the MVRHP is highly recommended in both conventional process and RD column with a separation unit. Significant reduction in energy consumption and total utilities cost was achieved. When using MVRHP, heating demands were reduced by $42.3 \%$ (Conventional process with an MVRHP (Figure 4)) and by $62.3 \%$ (RD column with a separation unit and an MVRHP (Figure 6)). Cooling duty savings of up to $37.5 \%$ (conventional process with an MVRHP in Figure 4) and up to $56.2 \%$ (RD column with a separation unit and an MVRHP in Figure 6) can be achieved. Moreover, total utilities cost was reduced by 21.3\% (conventional process with an MVRHP in Figure 4) and by 37.0\% (RD column with a separation unit and an MVRHP in Figure 6). Consequently, the MVRHP enables improving the pay-back period of processes originally designed in our previous work [5] despite the increased capital cost due to the compressor price and process changes. The energy and economic assessment showed that the RD column with a separation unit and an MVRHP is the most promising concept. On the contrary, individual risk assessment showed that the MVRHP use leads to increased risk hazard. Finally, integrated and intensified RD column with a separation unit and an MVRHP and thermally coupled process (RDS) were compared, both processes showing similar total energy requirements; however, the total capital cost, pay-back period and individual risk assessment proved the RDS process to be much preferred compared to the process with an MVRHP.

Author Contributions: Conceptualization, B.Š. and Z.L.; Data curation, B.Š.; Formal analysis, B.Š. and Z.L.; Funding acquisition, Z.L.; Investigation, B.Š. and M.V.; Methodology, B.Š., J.L. and M.V.; Project administration, Z.L.; Resources, B.Š. and M.V.; Software, B.Š. and J.L.; Supervision, Z.L.; Validation, B.Š. and Z.L.; Visualization, B.Š.; Writing—original draft, B.Š., J.L., M.V. and Z.L.; Writingreview and editing, B.Š., J.L. and Z.L. All authors have read and agreed to the published version of the manuscript.

Funding: This research was funded by the Slovak Research and Development Agency, under the contract No. APVV-18-0134 and by the Slovak Scientific Agency, Grant No. VEGA 1/0511/21.

Data Availability Statement: The data presented in this study are obtained from simulation results. Adopted data are obtained from cited literature.

Conflicts of Interest: The authors declare no conflict of interest.

\section{List of Symbols}

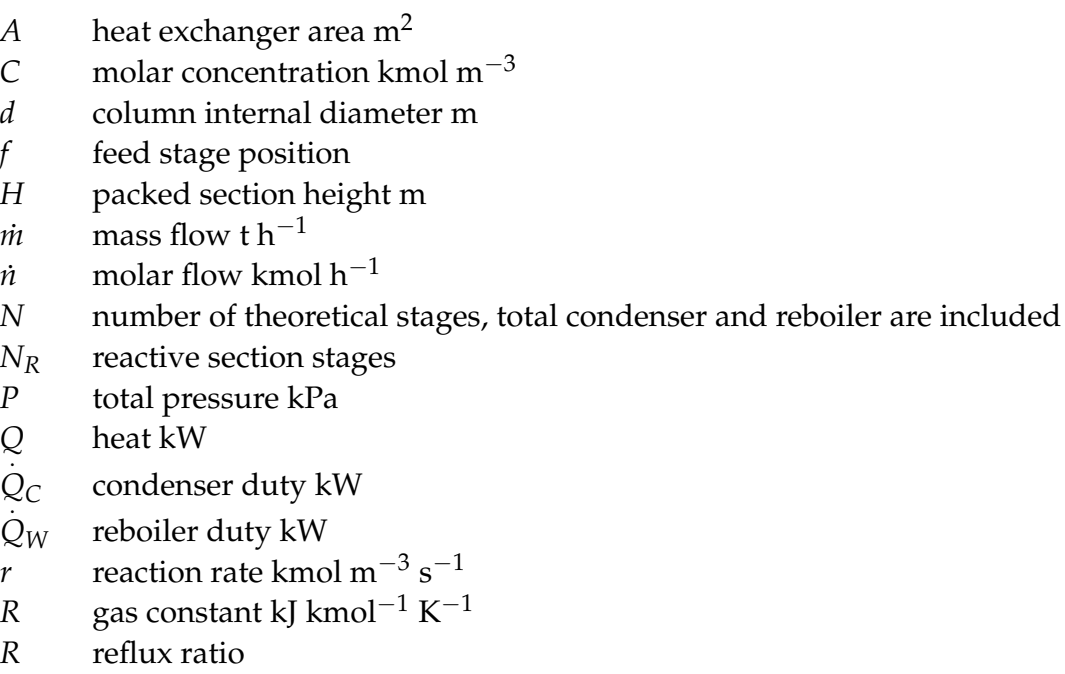


$T \quad$ temperature ${ }^{\circ} \mathrm{C}$

$T$ thermodynamic temperature in Equation (4) $\mathrm{K}$

$\dot{V} \quad$ volume flow $\mathrm{m}^{3} \mathrm{~h}^{-1}$

$W$ compressor required network $\mathrm{kW}$

$x$ molar fraction in the liquid phase

$\eta_{E} \quad$ reference efficiency of electricity production

$\eta_{Q}$ reference efficiency of heat production

\section{Subscripts}

$\begin{array}{ll}\text { AA } & \text { acetic acid } \\ C & \text { condenser } \\ D & \text { distillate } \\ E & \text { electricity } \\ \text { EtAc } & \text { ethyl acetate } \\ \text { EtO } & \text { Hethanol } \\ F & \text { feed } \\ \mathrm{H}_{2} \mathrm{O} & \text { water } \\ Q & \text { heat } \\ R & \text { reaction occurrence } \\ W & \text { reboiler }\end{array}$

\section{Abbreviations}

$\begin{array}{ll}\text { AA } & \text { acetic acid } \\ \text { AOC } & \text { annual operation cost } \\ \text { ASC } & \text { annualized separation costs } \\ \text { COP } & \text { coefficient of performance } \\ \text { CSTR } & \text { continuous stirred tank reactor } \\ \text { EQ } & \text { equilibrium } \\ \text { EtAc } & \text { ethyl acetate } \\ \text { EtOH } & \text { ethanol } \\ \text { HOC } & \text { Hayden-O'Connell equation of state } \\ \text { HP } & \text { heat pump } \\ \text { MVRHP } & \text { mechanical vapor recompression heat pump } \\ \text { NEQ } & \text { non-equilibrium } \\ \text { NRTL } & \text { non-random two liquids } \\ \text { OEC } & \text { overall energy consumption } \mathrm{kW}^{-} \\ \text {PES } & \text { primary energy savings } \\ \text { RD } & \text { reactive distillation } \\ \text { RDS } & \text { reactive distillation with stripper column } \\ \text { RDAR } & \text { reactive distillation with auxiliary reaction } \\ \text { RDWC } & \text { reactive distillation with a dividing wall } \\ \text { SEC } & \text { specific energy consumption } \mathrm{kWh}^{-1} \mathrm{EtAc}^{-1} \\ \text { TAC } & \text { total annual cost USD year } \\ \text { TCC } & \text { total capital cost USD } \\ \text { TPC } & \text { total production cost USD } \mathrm{t}^{-1} \\ \text { VL } & \text { vapor-liquid } \\ \text { VLLE } & \text { vapor-liquid-liquid phase equilibria }\end{array}$




\section{Appendix A}

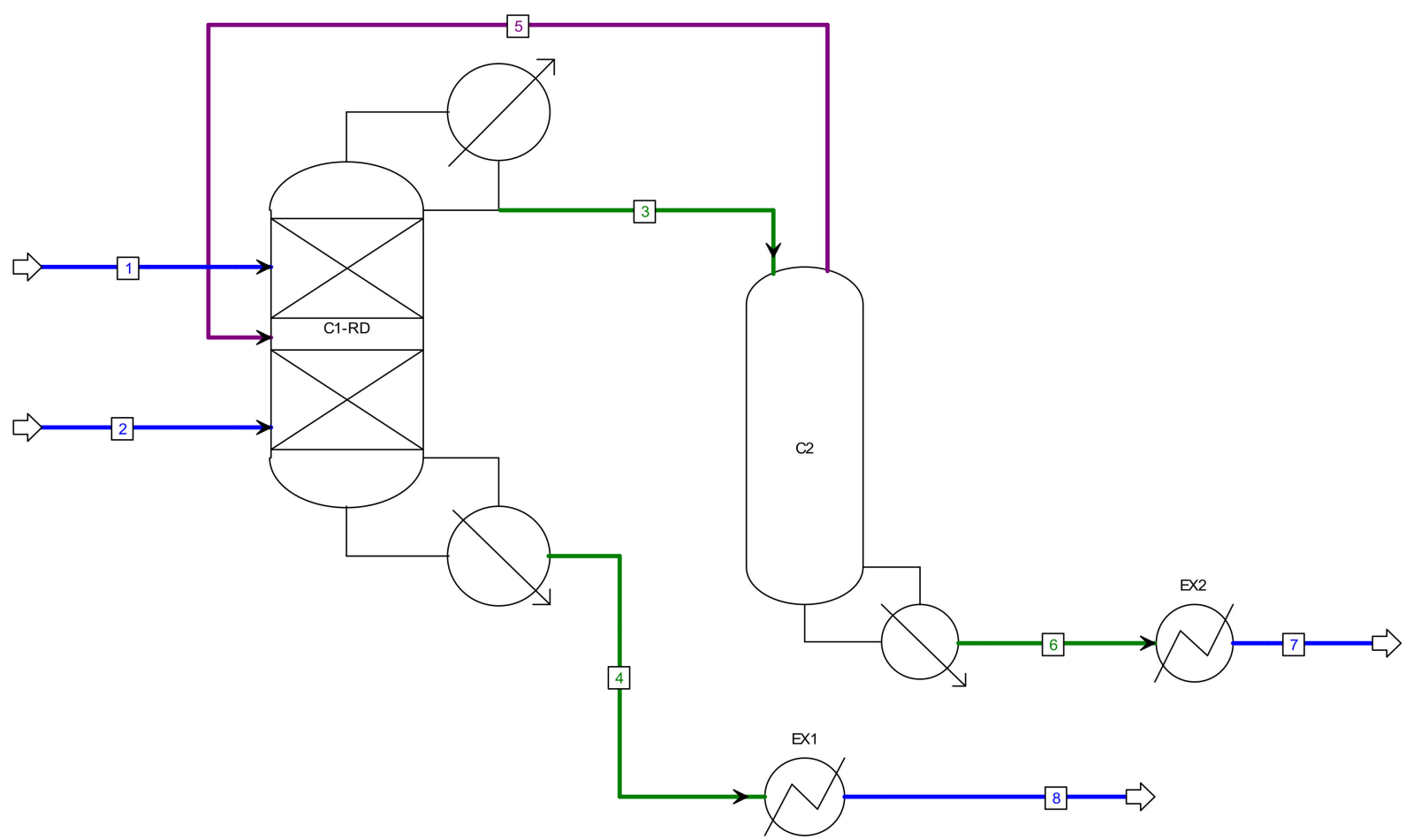

Figure A1. Ethyl acetate production via reactive distillation column with a stripper adapted from our previous work [5]. Stream condition: blue—subcooled liquid; green—liquid at boiling temperature; purple—saturated/overheated vapor. C1-RD—reactive distillation column; C2—stripper column; EX1, EX2—heat exchangers. 


\section{Appendix B}

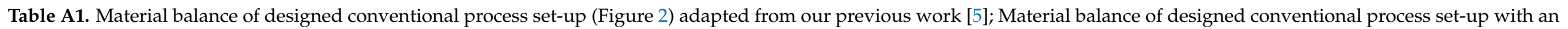
MVRHP (Figure 4).

\begin{tabular}{|c|c|c|c|c|c|c|c|c|c|c|c|c|c|c|c|c|c|}
\hline & 1 & 2 & 3 & 4 & 5 & 6 & 7 & 8 & 9 & 10 & 11 & 12 & 13 & 14 & 15 & 16 & 17 \\
\hline$\dot{n}\left[\mathrm{kmol} \mathrm{h}^{-1}\right]$ & 10.00 & 10.00 & 19.88 & 22.64 & 42.52 & 42.52 & 42.52 & 12.65 & 12.65 & 39.86 & 187.78 & 187.78 & 41.21 & 41.21 & 21.21 & 21.21 & 20.00 \\
\hline$x_{\mathrm{H} 2 \mathrm{O}}$ & - & - & 0.0869 & - & 0.0407 & 0.2756 & 0.2756 & - & - & 0.2940 & 0.7608 & 0.7608 & 0.1604 & 0.1604 & 0.3114 & 0.3114 & 0.0003 \\
\hline$x_{\mathrm{AA}}$ & 1.0000 & - & - & 0.8325 & 0.4433 & 0.2083 & 0.2083 & 0.7000 & 0.7000 & - & - & - & - & - & - & - & - \\
\hline$x_{\mathrm{EtOH}}$ & - & 1.0000 & 0.7830 & 0.0002 & 0.3662 & 0.1312 & 0.1312 & 0.0004 & 0.0004 & 0.1400 & 0.0536 & 0.0536 & 0.0724 & 0.0724 & 0.1399 & 0.1399 & 0.0007 \\
\hline$T\left[{ }^{\circ} \mathrm{C}\right]$ & 25.00 & 25.00 & 29.38 & 39.64 & 36.98 & 39.01 & 54.24 & 98.20 & 49.01 & 70.02 & 48.97 & 25.00 & 25.00 & 41.79 & 70.02 & 35.00 & 76.83 \\
\hline$P[\mathrm{kPa}]$ & 101.3 & 101.3 & 101.3 & 101.3 & 101.3 & 101.3 & 101.3 & 101.3 & 101.3 & 101.3 & 101.3 & 101.3 & 101.3 & 101.3 & 101.3 & 101.3 & 101.3 \\
\hline \multirow[t]{2}{*}{$V\left[\mathrm{~m}^{3} \mathrm{~h}^{-1}\right]$} & 0.56 & 0.58 & 1.19 & 1.44 & 2.65 & 2.66 & 2.72 & 0.95 & 0.88 & 2.90 & 6.71 & 6.50 & 3.37 & 3.45 & 1.51 & 1.43 & 2.12 \\
\hline & 18 & 19 & 20 & 21 & 22 & 23 & 24 & $25^{a}$ & 26 & 27 & 28 & 29 & 30 & 31 & 32 & 33 & \\
\hline$\dot{n}\left[\mathrm{kmol} \mathrm{h}^{-1}\right]$ & 10.00 & 10.00 & 10.00 & 146.57 & 29.31 & 117.26 & 117.26 & 117.26 & 107.38 & 107.38 & 97.37 & 10.00 & 10.00 & 126.69 & 9.87 & 9.87 & \\
\hline$x_{\mathrm{H} 2 \mathrm{O}}$ & 0.0003 & 0.0003 & 0.0003 & 0.9296 & 0.9296 & 0.9296 & 0.9296 & 0.9296 & 0.9990 & 0.9990 & 0.9990 & 0.9990 & 0.9990 & 0.9829 & 0.1749 & 0.1749 & \\
\hline$x_{\mathrm{AA}}$ & - & - & - & - & - & - & - & - & - & - & - & - & - & - & - & - & \\
\hline$x_{\text {EtAc }}$ & 0.9990 & 0.9990 & 0.9990 & 0.0220 & 0.0220 & 0.0220 & 0.0220 & 0.0220 & - & - & - & - & - & 0.0051 & 0.2619 & 0.2619 & \\
\hline$x_{\mathrm{EtOH}}$ & 0.0007 & 0.0007 & 0.0007 & 0.0484 & 0.0484 & 0.0484 & 0.0484 & 0.0484 & 0.0010 & 0.0010 & 0.0010 & 0.0010 & 0.0010 & 0.0120 & 0.5632 & 0.5632 & \\
\hline$T\left[{ }^{\circ} \mathrm{C}\right]$ & 76.83 & 76.83 & 25.00 & 25.00 & 25.00 & 25.00 & 30.34 & 72.79 & 99.34 & 40.34 & 40.34 & 40.34 & 40.34 & 36.54 & 71.69 & 35.00 & \\
\hline$P[\mathrm{kPa}]$ & 101.3 & 101.3 & 101.3 & 101.3 & 101.3 & 101.3 & 101.3 & 101.3 & 101.3 & 101.3 & 101.3 & 101.3 & 101.3 & 101.3 & 101.3 & 101.3 & \\
\hline$V\left[\mathrm{~m}^{3} \mathrm{~h}^{-1}\right]$ & 1.06 & 1.06 & 0.98 & 3.18 & 0.64 & 2.55 & 2.56 & $59.33^{a}$ & 2.11 & 1.98 & 1.80 & 0.00 & 0.18 & 2.43 & 0.65 & 0.61 & \\
\hline
\end{tabular}


Table A2. Material balance of designed conventional process set-up with an MVRHP (Figure 4): heat pump subsystem.

\begin{tabular}{|c|c|c|c|c|c|c|c|c|c|c|c|}
\hline & 34 & 35 & $36^{a}$ & $37^{a}$ & $38^{a}$ & $39^{b}$ & 40 & 41 & 42 & 43 & 44 \\
\hline$\dot{n}\left[\mathrm{kmol} \mathrm{h}^{-1}\right]$ & 172.89 & 172.89 & 152.77 & 136.92 & 154.20 & 154.20 & 154.20 & 154.20 & 154.20 & 137.05 & 115.84 \\
\hline$x_{\mathrm{H} 2 \mathrm{O}}$ & 0.0009 & 0.0009 & 0.0009 & 0.3131 & 0.3051 & 0.3051 & 0.3051 & 0.3051 & 0.3051 & 0.3128 & 0.3131 \\
\hline$x_{\mathrm{AA}}$ & 0.0000 & 0.0000 & 0.0000 & 0.0000 & 0.0000 & 0.0000 & 0.0000 & 0.0000 & 0.0000 & 0.0000 & 0.0000 \\
\hline$x_{\mathrm{EtOH}}$ & 0.0011 & 0.0011 & 0.0012 & 0.1408 & 0.1425 & 0.1425 & 0.1425 & 0.1425 & 0.1425 & 0.1407 & 0.1408 \\
\hline$T\left[{ }^{\circ} \mathrm{C}\right]$ & 78.80 & 78.83 & 78.83 & 71.95 & 71.40 & 108.73 & 96.48 & 94.77 & 71.94 & 71.41 & 71.41 \\
\hline vapor fraction & 0 & 0.88 & 1 & 1 & 1 & 1 & 0.05 & 0 & 0.11 & 0 & 0 \\
\hline$P[\mathrm{kPa}]$ & 101.3 & 101.3 & 101.3 & 101.3 & 101.3 & 250.0 & 240.0 & 240.0 & 101.3 & 101.3 & 101.3 \\
\hline
\end{tabular}

${ }^{a}$ saturated vapor; ${ }^{b}$ overheated vapor.

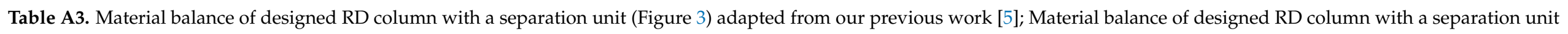
and an MVRHP (Figure 6).

\begin{tabular}{|c|c|c|c|c|c|c|c|c|c|c|c|c|c|c|}
\hline & 1 & 2 & 3 & 4 & 5 & 6 & 7 & 8 & 9 & 10 & 11 & 12 & 13 & 14 \\
\hline$\dot{n}\left[\mathrm{kmol} \mathrm{h}^{-1}\right]$ & 10.00 & 10.00 & 20.94 & 7.72 & 40.60 & 30.59 & 30.59 & 30.59 & 19.66 & 19.66 & 10.00 & 10.00 & 69.62 & 77.34 \\
\hline$x_{\mathrm{H} 2 \mathrm{O}}$ & - & - & 0.2666 & 0.7918 & 0.2165 & 0.2873 & 0.2873 & 0.2873 & 0.1632 & 0.1632 & 0.0002 & 0.0002 & 0.9227 & 0.9096 \\
\hline$x_{\mathrm{AA}}$ & 1.0000 & - & - & - & - & - & - & - & - & - & - & - & - & - \\
\hline$x_{\mathrm{EtAc}}$ & - & - & 0.5536 & - & 0.6515 & 0.5378 & 0.5378 & 0.5378 & 0.7558 & 0.7558 & 0.9990 & 0.9990 & 0.0229 & 0.0206 \\
\hline$x_{\mathrm{EtOH}}$ & - & 1.0000 & 0.1798 & 0.2082 & 0.1320 & 0.1749 & 0.1749 & 0.1749 & 0.0811 & 0.0811 & 0.0008 & 0.0008 & 0.0544 & 0.0697 \\
\hline$T\left[{ }^{\circ} \mathrm{C}\right]$ & 25.00 & 25.00 & 70.02 & 82.47 & 64.47 & 70.01 & 45.84 & 25.00 & 25.00 & 60.00 & 76.84 & 25.00 & 25.00 & 31.20 \\
\hline$P[\mathrm{kPa}]$ & 101.3 & 101.3 & 101.3 & 101.3 & 101.3 & 101.3 & 101.3 & 101.3 & 101.3 & 101.3 & 101.3 & 101.3 & 101.3 & 101.3 \\
\hline \multirow[t]{2}{*}{$V\left[\mathrm{~m}^{3} \mathrm{~h}^{-1}\right]$} & 0.56 & 0.58 & 1.54 & 0.22 & 3.21 & 2.20 & 2.12 & 2.06 & 1.59 & 1.68 & 1.06 & 0.98 & 1.53 & 1.75 \\
\hline & $15^{a}$ & 16 & 17 & 18 & 19 & 20 & 21 & 22 & & & & & & \\
\hline$\dot{n}\left[\mathrm{kmol} \mathrm{h}^{-1}\right]$ & 77.34 & 8.66 & 18.66 & 68.70 & 68.70 & 68.70 & 58.67 & 10.02 & & & & & & \\
\hline$x_{\mathrm{H} 2 \mathrm{O}}$ & 0.9096 & 0.1958 & 0.0909 & 0.9995 & 0.9995 & 0.9995 & 0.9995 & 0.9995 & & & & & & \\
\hline$x_{\mathrm{AA}}$ & - & - & - & - & - & - & - & - & & & & & & \\
\hline$x_{\mathrm{EtAc}}$ & 0.0206 & 0.1842 & 0.0855 & - & - & - & - & - & & & & & & \\
\hline$x_{\mathrm{EtOH}}$ & 0.0698 & 0.6200 & 0.8236 & 0.0005 & 0.0005 & 0.0005 & 0.0005 & 0.0005 & & & & & & \\
\hline$T\left[{ }^{\circ} \mathrm{C}\right]$ & 72.04 & 72.65 & 47.88 & 99.50 & 45.00 & 25.00 & 25.00 & 25.00 & & & & & & \\
\hline$P[\mathrm{kPa}]$ & 101.3 & 101.3 & 101.3 & 101.3 & 101.3 & 101.3 & 101.3 & 101.3 & & & & & & \\
\hline$V\left[\mathrm{~m}^{3} \mathrm{~h}^{-1}\right]$ & $19.65^{a}$ & 0.53 & 1.11 & 1.35 & 1.27 & 1.25 & 1.06 & 0.18 & & & & & & \\
\hline
\end{tabular}


Table A4. Material balance of designed RD column with a separation unit and an MVRHP (Figure 6): heat pump subsystem.

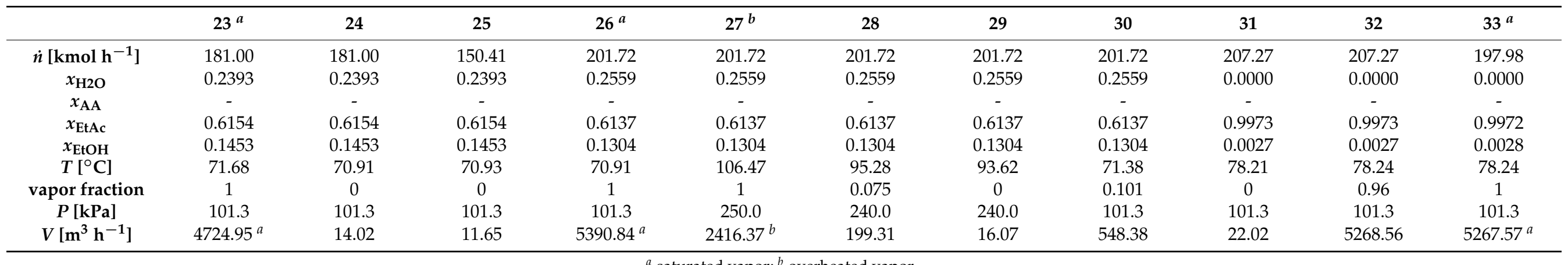

Table A5. Equipment cost and total installed cost of individual equipment

\begin{tabular}{|c|c|c|c|c|c|c|c|c|}
\hline & \multicolumn{2}{|c|}{$\begin{array}{l}\text { Conventional Process } \\
\text { (Figure 2) }\end{array}$} & \multicolumn{2}{|c|}{$\begin{array}{c}\text { Conventional Process with an MVRHP } \\
\text { (Figure 4) }\end{array}$} & \multicolumn{2}{|c|}{$\begin{array}{l}\text { RD Column with a Separation Unit } \\
\text { (Figure 3) }\end{array}$} & \multicolumn{2}{|c|}{$\begin{array}{l}\text { RD Column with a Separation Unit and an MVRHP } \\
\text { (Figure 6) }\end{array}$} \\
\hline & Equipment Cost & Installed Cost & Equipment Cost & Installed Cost & Equipment Cost & Installed Cost & Equipment Cost & Installed Cost \\
\hline Item & {$\left[10^{3}\right.$ USD] } & {$\left[10^{3}\right.$ USD] } & {$\left[10^{3}\right.$ USD] } & {$\left[10^{3}\right.$ USD] } & {$\left[10^{3}\right.$ USD $]$} & {$\left[10^{3}\right.$ USD $]$} & {$\left[10^{3}\right.$ USD] } & {$\left[10^{3}\right.$ USD] } \\
\hline CSTR & 173.7 & 334.3 & 173.7 & 334.3 & - & - & - & - \\
\hline C1/C1-RD & 620.7 & 1147.2 & 620.7 & 1147.2 & 680.5 & 1214.0 & 680.5 & 1214.0 \\
\hline $\mathrm{C} 2$ & 594.5 & 1138.1 & $543.2^{a}$ & $864.2^{a}$ & 610.6 & 1185.2 & $551.9^{a}$ & $881.2^{a}$ \\
\hline K1 & - & - & 344.7 & 551.5 & - & - & 376.3 & 602.1 \\
\hline C3 & 172.6 & 564.0 & 172.6 & 564.0 & 148.0 & 487.8 & 148.0 & 487.8 \\
\hline DEC & 16.1 & 108.9 & 16.1 & 108.9 & 16.1 & 108.9 & 16.1 & 108.9 \\
\hline EX1 & 8.5 & 53.0 & 8.5 & 53.0 & 8.7 & 59.1 & 8.7 & 59.1 \\
\hline EX2 & 39.3 & 120.0 & 39.3 & 120.0 & 19.3 & 85.4 & 19.3 & 85.4 \\
\hline EX3 & 8.7 & 59.1 & 8.7 & 59.1 & 9.9 & 62.6 & 9.9 & 62.6 \\
\hline EX4 & 8.5 & 45.7 & 8.5 & 45.7 & 14.3 & 70.7 & 14.3 & 70.7 \\
\hline EX5 & 11.0 & 63.9 & 11.0 & 63.9 & 10.9 & 60.8 & 10.9 & 60.8 \\
\hline EX6 & 8.5 & 45.7 & 8.5 & 45.7 & - & - & $42.4^{b}$ & $127.0^{b}$ \\
\hline EX7 & 10.5 & 60.3 & 10.5 & 60.3 & - & - & 37.7 & 93.4 \\
\hline EX8 & - & - & $34.8^{b}$ & $116.1^{b}$ & - & - & - & - \\
\hline EX9 & - & - & 35.9 & 87.6 & - & - & - & - \\
\hline Sum & 1672.6 & 3740.2 & 2036.7 & 4221.5 & 1518.3 & 3334.5 & 1916.0 & 3853.0 \\
\hline
\end{tabular}




\section{References}

1. Riemenschneider, W.; Bolt, H.M. Esters, Organic. In Ullmann's Encyclopedia of Industrial Chemistry; Wiley-VCH Verlag GmbH \& Co. KGaA: Weinheim, Germany, 2012. [CrossRef]

2. Srinivasan, R.; Nhan, N.T. A statistical approach for evaluating inherent benign-ness of chemical process routes in early design stages. Process Saf. Environ. Prot. 2008, 86, 163-174. [CrossRef]

3. Li, C.; Duan, C.; Fang, J.; Li, H. Process intensification and energy saving of reactive distillation for production of ester compounds. Chin. J. Chem. Eng. 2019, 27, 1307-1323. [CrossRef]

4. Santaella, M.A.; Orjuela, A.; Narváez, P.C. Comparison of different reactive distillation schemes for ethyl acetate production using sustainability indicators. Chem. Eng. Process. Process Intensif. 2015, 96, 1-13. [CrossRef]

5. Šulgan, B.; Labovský, J.; Labovská, Z. Multi-Aspect Comparison of Ethyl Acetate Production Pathways: Reactive Distillation Process Integration and Intensification via Mechanical and Chemical Approach. Processes 2020, 8, 1618. [CrossRef]

6. Toth, A.J. Comprehensive evaluation and comparison of advanced separation methods on the separation of ethyl acetate-ethanolwater highly non-ideal mixture. Sep. Purif. Technol. 2019, 224, 490-508. [CrossRef]

7. Kiss, A.A.; Jobson, M. Taking Reactive Distillation to the Next Level of Process Intensification. Chem. Eng. Trans. 2018, 69, 553-558. [CrossRef]

8. Segovia-Hernández, J.G.; Hernández, S.; Bonilla Petriciolet, A. Reactive distillation: A review of optimal design using deterministic and stochastic techniques. Chem. Eng. Process. Process Intensif. 2015, 97, 134-143. [CrossRef]

9. Hu, S.; Zhang, B.; Hou, X.; Li, D.; Chen, Q. Design and simulation of an entrainer-enhanced ethyl acetate reactive distillation process. Chem. Eng. Process. Process Intensif. 2011, 50, 1252-1265. [CrossRef]

10. Tavan, Y.; Behbahani, R.M.; Hosseini, S.H. A novel intensified reactive distillation process to produce pure ethyl acetate in one column-Part I: Parametric study. Chem. Eng. Process. Process Intensif. 2013, 73, 81-86. [CrossRef]

11. Xie, J.; Li, C.; Peng, F.; Dong, L.; Ma, S. Experimental and simulation of the reactive dividing wall column based on ethyl acetate synthesis. Chin. J. Chem. Eng. 2018, 26, 1468-1476. [CrossRef]

12. Calvar, N.; González, B.; Dominguez, A. Esterification of acetic acid with ethanol: Reaction kinetics and operation in a packed bed reactive distillation column. Chem. Eng. Process. Process Intensif. 2007, 46, 1317-1323. [CrossRef]

13. Harmsen, G.J. Reactive distillation: The front-runner of industrial process intensification. Chem. Eng. Process. Process Intensif. 2007, 46, 774-780. [CrossRef]

14. Kiss, A.A. Energy Efficient Distillation Powered By Heat Pumps Upgrading Low Quality Energy To Drive the Reboiler of the Column. NPT Procestechnol. 2014, 2, 15-17.

15. Jana, A.K. Advances in heat pump assisted distillation column: A review. Energy Convers. Manag. 2014, 77, 287-297. [CrossRef]

16. Joda, F.; Ahmadi, F. Exergoeconomic analysis of conventional and using reactive distillation biodiesel production scenarios thermally integrated with a combined power plan. Renew. Energy 2019, 132, 898-910. [CrossRef]

17. Feng, S.; Ye, Q.; Xia, H.; Li, R.; Suo, X. Integrating a vapor recompression heat pump into a lower partitioned reactive dividing-wall column for better energy-saving performance. Chem. Eng. Res. Des. 2017, 125, 204-213. [CrossRef]

18. Shi, L.; Wang, S.J.; Huang, K.; Wong, D.S.H.; Yuan, Y.; Chen, H.; Zhang, L.; Wang, S. Intensifying reactive dividing-wall distillation processes via vapor recompression heat pump. J. Taiwan Inst. Chem. Eng. 2017, 78, 8-19. [CrossRef]

19. Liu, Y.; Zhai, J.; Li, L.; Sun, L.; Zhai, C. Heat pump assisted reactive and azeotropic distillations in dividing wall columns. Chem. Eng. Process. Process Intensif. 2015, 95, 289-301. [CrossRef]

20. Christopher, C.C.E.; Dutta, A.; Farooq, S.; Karimi, I.A. Process Synthesis and Optimization of Propylene/Propane Separation Using Vapor Recompression and Self-Heat Recuperation. Ind. Eng. Chem. Res. 2017, 56, 14557-14564. [CrossRef]

21. Feng, Z.; Shen, W.; Rangaiah, G.P.; Dong, L. Design and control of vapor recompression assisted extractive distillation for separating n-hexane and ethyl acetate. Sep. Purif. Technol. 2020, 240, 116655. [CrossRef]

22. Dai, M.; Yang, F.; Zhang, Z.; Liu, G.; Feng, X. Energetic, economic and environmental (3E) multi-objective optimization of the back-end separation of ethylene plant based on adaptive surrogate model. J. Clean. Prod. 2021, 310, 127426. [CrossRef]

23. Sharon, H. Energy, exergy, environmental benefits and economic aspects of novel hybrid solar still for sustainable water distillation. Process Saf. Environ. Prot. 2021, 150, 1-21. [CrossRef]

24. Klauzner, P.S.; Rudakov, D.G.; Anokhina, E.A.; Timoshenko, A.V. Use of Partially Thermally Coupled Distillation Systems and Heat Pumps for Reducing the Energy Consumption in the Extractive Distillation of an Isobutanol-Isobutyl Acetate Mixture Using Dimethylformamide. Theor. Found. Chem. Eng. 2020, 54, 397-406. [CrossRef]

25. Shi, X.; Zhu, X.; Zhao, X.; Zhang, Z. Performance evaluation of different extractive distillation processes for separating ethanol/tertbutanol/water mixture. Process Saf. Environ. Prot. 2020, 137, 246-260. [CrossRef]

26. Zhang, Q.; Yang, S.; Shi, P.; Hou, W.; Zeng, A.; Ma, Y.; Yuan, X. Economically and thermodynamically efficient heat pump-assisted side-stream pressure-swing distillation arrangement for separating a maximum-boiling azeotrope. Appl. Therm. Eng. 2019, 173, 115228. [CrossRef]

27. Cong, H.; Murphy, J.P.; Li, X.; Li, H.; Gao, X. Feasibility Evaluation of a Novel Middle Vapor Recompression Distillation Column. Ind. Eng. Chem. Res. 2018, 57, 6317-6329. [CrossRef]

28. Van Duc Long, N.; Han, T.H.; Lee, D.Y.; Park, S.Y.; Hwang, B.B.; Lee, M. Enhancement of a R-410A reclamation process using various heat-pump-assisted distillation configurations. Energies 2019, 12, 3776. [CrossRef] 
29. Duan, C.; Li, C. Novel energy-saving methods to improve the three-column extractive distillation process for separating ethyl acetate and ethanol using furfural. Sep. Purif. Technol. 2021, 272, 118887. [CrossRef]

30. Shi, T.; Chun, W.; Yang, A.; Su, Y.; Jin, S.; Ren, J.; Shen, W. Optimization and control of energy saving side-stream extractive distillation with heat integration for separating ethyl acetate-ethanol azeotrope. Chem. Eng. Sci. 2020, 215, 115373. [CrossRef]

31. Parmar, K.K.; Parmar, K.K.; Padmavathi, G.; Dash, S.K. Energy reduction and improved product recovery with enhanced safety of industrial scale propane-propylene separation process. Int. J. Energy Res. 2020, 44, 12630-12638. [CrossRef]

32. Ifaei, P.; Safder, U.; Yoo, C.K. Multi-scale smart management of integrated energy systems, Part 1: Energy, economic, environmental, exergy, risk (4ER) and water-exergy nexus analyses. Energy Convers. Manag. 2019, 197, 111851. [CrossRef]

33. Official Journal of the European Union. Available online: https:/ / eur-lex.europa.eu/LexUriServ/LexUriServ.do?uri=OJ:L:2007: 032:0183:0188:SK:PDF (accessed on 17 May 2021).

34. Couper, J.R.; Hertz, D.W.; Smith, F.L. Process Economics. In Perry's Chemical Engineers' Handbook; Green, D.W., Perry, R.H., Eds.; McGraw-Hill: New York, NY, USA, 2007; Volume 848.

35. The Center for Chemical Process Safety. Guidelines for Chemical Process. Quantitative Risk Analysis; American Institute of Chemical Engineers: New York, NY, USA, 1989.

36. Trofimova, M.; Sadaev, A.; Samarov, A.; Golikova, A.; Tsvetov, N.; Toikka, M.; Toikka, A. Liquid-liquid equilibrium of acetic acid-ethanol-ethyl acetate-water quaternary system: Data review and new results at $323.15 \mathrm{~K}$ and $333.15 \mathrm{~K}$. Fluid Phase Equilib. 2020, 503, 112321. [CrossRef]

37. Singh, D.; Gupta, R.K.; Kumar, V. Simulation of a plant scale reactive distillation column for esterification of acetic acid. Comput. Chem. Eng. 2015, 73, 70-81. [CrossRef]

38. Pavlíček, J.; Bogdanić, G.; Wichterle, I. Vapour-liquid and chemical equilibria in the ethyl ethanoate+ethanol+propyl ethanoate+propanol system accompanied with transesterification reaction. Fluid Phase Equilib. 2012, 328, 61-68. [CrossRef]

39. ASPEN Technology. Aspen Plus®: Aspen Plus User Guide; Version 12.0; Aspen Technology Inc.: Cambridge, MA, USA, 2000.

40. Hayden, J.G.; O'Connell, J.P. A Generalized Method for Predicting Second Virial Coefficients. Ind. Eng. Chem. Process Des. Dev. 1975, 14, 209-216. [CrossRef]

41. Eilerman, R.G.; Staff, U. Cinnamic Acid, Cinnamaldehyde, and Cinnamyl Alcohol. In Kirk-Othmer Encyclopedia of Chemical Technology; John Wiley \& Sons, Inc.: Hoboken, NJ, USA, 2014; pp. 1-11.

42. GPSA (Gas Processors Supplier Associations) Engineering Data Book; Gas Processors Supplier Associations: Tulsa, OK, USA, 1979.

43. Walas, S.M.; Couper, J.R.; Penney, W.R.; Fair, J.R. Chemical Process Equipment: Selection and Design; Elsevier Inc.: Oxford, UK, 2009.

44. Chembid. Available online: www.chembid.com (accessed on 20 May 2021).

45. Molbase. Available online: www.molbase.com (accessed on 20 May 2021).

46. Löser, C.; Urit, T.; Bley, T. Perspectives for the biotechnological production of ethyl acetate by yeasts. Appl. Microbiol. Biotechnol. 2014, 98, 5397-5415. [CrossRef] [PubMed]

47. Hamels, S. $\mathrm{CO}_{2}$ Intensities and Primary Energy Factors in the Future European Electricity System. Energies 2021, $14,2165$. [CrossRef]

48. Vílchez, J.A.; Espejo, V.; Casal, J. Generic event trees and probabilities for the release of different types of hazardous materials. J. Loss Prev. Process Ind. 2011, 24, 281-287. [CrossRef] 